\title{
Strategic Bargaining and the Economic Theory of Contract Default Rules
}

\author{
Jason Scott Johnston $\uparrow$
}

In the economic analysis of law, famous cases are often famous not so much because of how courts have actually interpreted and applied them, but because they suggest potentially efficient legal rules. In this way, the rule of a famous case comes to represent a particular set of efficiency arguments, and these arguments become as foundational to the economic analysis of law as are the cases to doctrine. But economic explanations of doctrinal efficiency are themselves grounded in certain assumptions and conventions. Indeed, one of the valuable things about the economic approach to law is its straightforward statement of the assumptions from which analysis proceeds. ${ }^{1}$ To treat a particular efficiency argument as an established "rule" is therefore to treat argument as myth and to lose what is perhaps most valuable about the economic approach: the potential to progressively entich our understanding of legal rules and institutions by examining their efficiency under progressively more realistic, if more complex, behavioral and environmental assumptions.

This Article attempts to further the progressive research program of law and economics by questioning the established economic analysis of one of the foundational contract law cases, Hadley v. Baxendale. ${ }^{2}$ By limiting the extent of promissory liability for consequential damages to those which are "foreseeable,"3 Hadley exemplifies a "default" contract rule: an implicit term of a

$\dagger$ Associate Professor, Vanderbilt University School of Law. B.A., Dartmouth College; J.D., Ph.D. (Economics) The University of Michigan. I am grateful for financial support form the Civil Liability Program at Yale Law School, where I visited as a Fellow during 1988-89, and from the Dean's Fund at Vanderbilt Law School. While I am of course responsible for any errors which remain, this Article has greatly benefited from presentation before the Vanderbilt economics department's Microeconomic Theory Seminar, and from the written comments and criticism of Ian Ayres, Richard Craswell, Kenneth DauSchmidt, Richard Epstein, Daniel Farber, Avery Katz, Lewis Kornhauser, Richard Posner, Robert Rasmussen, and Alan Schwartz. Finally, I am especially grateful to Peter Cramton for sharing his thoughts both about the problem $I$ look at in this Article and about game theory in general.

1. For an elaboration of this view, and an explication of the varying methodologies within law and economics, see Johnston, Law, Economics and Post-Realist Explanation, 25 LAW \& Soc. REV. (forthcoming 1990).

2. 9 Ex. 341, 156 Eng. Rep. 145 (1854). In the view of Grant Gilmore, "Hadley v. Baxendale is still, and presumably always will be, a fixed star in the jurisprudential firmament." G. GILMORE, THE DEATH OF CONIRACT 83 (1974).

3. There is of course a good deal of difficulty in reconciling the "foreseeability" principle which Hadley has come to represent with the actual decision and opinion in the case. I discuss this more fully, infra at 6-8. 
contract unless the contracting parties explicitly agree to vary it. ${ }^{4}$ Because Hadley represents a default rule on contractual liability, the economic analysis of Hadley is an analysis of both a particular legal rule-the foreseeability limitation on consequential loss liability - and a general rule of contract construction - the implied default term. Here, I draw on insights about strategic bargaining from contemporary game theory to argue against the grain of the established understanding of both the Hadley foreseeability test and default rules generally. In so doing, I hope to expand the economic understanding of default rules, and, at the same time, to contribute to the nascent relationship between law and game theory. ${ }^{5}$

In the established economic understanding, Hadley illustrates a "penalty" default rule: a rule which "forces" the revelation of information which the revealing party might generally wish not to reveal. ${ }^{6}$ In the Hadley situation, the default rule is taken ${ }^{7}$ to provide only limited promisor liability for promisee consequential loss. This rule penalizes a promisee who will suffer high consequential loss-such as large lost profits-by denying her recovery of much of her loss. Faced with the prospect of large uncompensated damages in the event of breach, the promisee will have an incentive to tell the promisor that she will suffer large lost profits. The promisor may then agree to be liable for the full extent of such a promisee's loss, but only if the promisee agrees to pay a higher price for the contract. The promisee and society must be better off with such a rule, because the information which the promisee is "forced" to reveal allows the promisor to take the optimal, fully informed level of precaution against breach.

For some years, my intuition has been that this story fails to account for strategic incentives in bargaining. Again, according to the established view a promisee who will suffer loss of exceptionally large profits if the promisor breaches is supposed to tell the promisor that performance is especially important and valuable, and then agree to some price increase in exchange for the promisor's agreement to accept liability for these exceptional losses. But if we

4. On the idea of default rules in contract law, see generally Ayres \& Gertner, Filling Gaps in Incomplete Contracts: An Economic Theory of Default Rules, 99 YALE L.J. 87 (1989); Craswell, Contract Law, Default Rules, and the Philosophy of Promising, 88 MICH. L. REv. 489 (1989); Goetz \& Scoth, The Limits of Expanded Choice: An Analysis of the Interactions Between Express and Implied Contract Terms, 73 CALIF. L. REV. 261 (1985).

5. The recently published book, E. RASMUSEN, GAMES AND INFORMATION: AN INTRODUCTION TO GAME THEORY (1989), promises to make the central concepts in game theory accessible for the first time to a fairly wide legal audience. It seems likely that game theory will play an increasingly important role in legal analysis, see Ayres, Playing Games with the Law, 42 STAN. L. REV. 101 (1990) (reviewing E. RASMUSSEN, GAMES AND INFORMATION), but there are, as yet, few articles in law journals which take this approach. See Ayres \& Gertner, supra note 4; Mnookin \& Wilson, Rational Bargaining and Market Efficiency: Understanding Pennzoil v. Texaco, 75 VA. L. REv. 295 (1989); Schwartz, A Theory of Loan Priorities, 18 J. LEGAL STUD. 209 (1989).

6. The term "penalty" default was coined by Ayres \& Gertner, supra note 4.

7. I say "taken" because the economic understanding of the rule in Hadley is not the same as the rule in Hadley as it has come to be interpreted and applied by courts. 
are talking about bargaining over the contract, then we are talking about a process of strategic information transmission, a process in which the promisee tries to persuade the promisor that she cannot pay a high price, and the promisor tries to persuade the promisee that she should. In this process, the promisee would generally want to convince the promisor that her value from performance is low-that is, that she will not make especially large profits from successful performance. And the promisor would want to persuade the promisee-especially one who will not be fully covered against all consequential loss-that performance is virtually a sure thing, so that the contract is very valuable to the promisee, and also that performance is very costly, so that the promisee must pay a relatively high price or else the promisor will walk away.

But then the general strategic incentives in this bargaining situation are directly at odds with the established information-forcing justification for the rule in Hadley: the promisee is supposed to reveal her crucial item of private information-her value from performance-and thus do what is generally completely contrary to her strategic interest in the bargaining game. The promisee is, moreover, supposed to do this even though there is no incentive for the promisor to reveal his key item of private information-the actual probability of breach. Generally, the higher the initial probability of breach under the limited liability default rule, the more the promisee benefits from getting the promisor to agree to increase his liability above this default. So bargaining around the Hadley default is more likely, the higher the promisee's estimation of the probability of breach under this default. But then we have a final strategic problem with bargaining around the Hadley default: to get the contract in the first place, the promisor generally wants to persuade the promisee that the breach probability is low. So to bargain around this default, the promisor must convey information which is generally directly contrary to his strategic interest in bargaining with the default. Put somewhat more simply, the promisor wants a profitable contract, but risks not getting any contract at all by seeking to extract a high price from the promisee in exchange for insuring the promisee against losses above what the default provides. Thus, the promisor will not have an interest in bargaining around the default.

At virtually every stage in this story, strategic incentives in bargaining seem to cut against the idea that the penalty default rule in Hadley can force promisees to reveal information. The story shows, moreover, how the established understanding neglects entirely the promisor's incentive to reveal information. But just as Hadley qua case stands as a fixed point in the common law, so too does Hadley as theory stand as a pillar in the economic analysis of contract law. How can it be that Hadley as a theory about bargaining around the law is so at odds with my simple intuitive story?

My goal in the remainder of this Article is to answer this question. The answer has, I think, at least two, related parts. First, existing formal (mathematical) economic models of the rule in Hadley have simpiy not been formulated 
to capture the kind of strategic incentives which my story identifies. The models therefore are actually special and correspond poorly to what the nontechnical person imagines when he thinks of "bargaining" around the law. Second, because, as I mentioned earlier, Hadley represents a general type of legal rule - the default rule - the validity of the established understanding of Hadley has tended to follow from the more general, established economic understanding of default rules. This general understanding-which I call the "Coasean Contractual Theory"-rests on an enormously powerful and influential insight, the Coase Theorem. ${ }^{8}$ But this insight and the theory constructed upon it also fail to account for strategic incentives, and instead simply assume that there is no impediment to bargaining other than direct transaction costs.

In Part I of this Article, I explain in detail how the absence of explicit consideration of bargaining incentives limits both the specific established understanding of Hadley and the general Coasean Contractual Theory. In Part II, I sketch some stylized stories depicting the strategic difficulties that are likely to arise when parties try to bargain around an information-forcing or penalty default such as the Hadley rule. My goal in Part II is to persuade the reader that even in admittedly simple models, strategic bargaining considerations tend to favor what I call "expansive" default rules, such as the "foreseeability" limitation which Hadley has actually become. I do not claim to have presented a general theory, and indeed I think that a truly general treatment of the bargaining problem in Hadley in fact would require more modeling horsepower than the game theoretic analysis of bargaining has yet developed. ${ }^{9}$ Still, my series of vignettes argues that expansive default rules often eliminate strategic impediments to bargaining around the default.

Having made these points about bargaining incentives, it remains possible that I will have said little about the actual efficiency of expansive default rules, for it may be that even though it is easy to bargain around such rules, almost everyone prefers the "penalty" default. That is, it may be that the Hadley rule really is no penalty at all, but rather simply what the majority would have contracted for anyway. By imposing an expansive default, we would then simply force people to incur needless transaction costs in bargaining around the law. Professor Richard Epstein has in fact recently mounted just this sort

8. See Coase, The Problem of Social Cost, 3 J.L. \& ECON. 1 (1960).

9. The intuitive story about Hadley which I have told above describes a sequential bargaining game with two-sided private information and correlated or dependent values. As I note in Part I.B, while there have been some very recent approaches to the one-sided correlated values problem, none of these deal with games involving mutually correlated private information. That is, this is a very difficult, and to the best of my knowledge unsolved, type of problem. For an analysis of auctions with mutually payoff-relevant information, see Cremer \& McLean, Optimal Selling Strategies Under Uncertainty for a Discriminating Monopolist When Demands are Interdependent, 53 ECONOMETRICA 345 (1985); for an analysis of transfer schemes, see Johnson, Pratt \& Zeckhauser, Efficiency Despite Mutually Payoff-Relevant Private Information: The Finite Case, 58 ECONOMETRICA 873 (1990). 
of empirical attack on expansive default rules, ${ }^{10}$ and empirical observations about the terms contained in "most" contracts of a given class are more generally an important part of the Coasean approach to default terms. ${ }^{11}$

In Part III of this Article, I meet the empiricist challenge to my theoretical results. I argue that an extensive (although admittedly incomplete and methodologically informal) survey of hundreds of cases on consequential damages over the last 120 years (which includes a period when Hadley was more stringently interpreted than it now is, as under Holmes' tacit agreement view) ${ }^{12}$ finds few cases where the promisee claimed to have done what the information-forcing theory says she should have done: nobody seems to have claimed that they told the promisor that they would suffer unusually large consequential damages. At the same time, there are scores of recent cases in which the parties apparently accepted the more expansive "foreseeability" version of Hadley. I do not contend that any of this constitutes conclusive empirical proof that most people like the "foreseeability" limitation and that those who do not are able to bargain around it. Rather, I contend merely that there is no conclusive evidence one way or the other. And I make the general point, made also by Ayres and Gertner, ${ }^{13}$ that just as people sometimes fail to bargain around a default rule not because the default is efficient for them but because there are strategic impediments to bargaining around it, the observation that lots of people bargain around a default rule does not imply that the rule they bargain to is the optimal default rule. It may be that the bargained-to rule would, for strategic reasons, not be bargained around were it the default rule.

Part III also points out the trouble the information-forcing theory of Hadley has in harmonizing Hadley with other, related contract doctrines such as the nondisclosure rule in Laidlaw v. Organ ${ }^{14}$ and the law's reluctance to enforce liquidated damage provisions. ${ }^{15}$ The law's reluctance to enforce liquidated damage provisions makes it very difficult for bargainers to do the very thing that the information-forcing theory says they should do. Laidlaw's accepted meaning within the economic analysis of law (which it must be stressed is, like Hadley's meaning, quite different than its meaning as actual contract doctrine) that it is undesirable to force the revelation of at least some kinds of information is also problematic for the information-forcing theory. Both of these related doctrines, however, are consistent with my theory.

Finally, in Part IV, I conclude with some limited remarks on the problems of positivism in the economic analysis of law that are raised by Hadley and

10. Epstein, Beyond Foreseeability: Consequential Damages in the Law of Contract, 18 J. LEGAL STUD. 105 (1989).

11. See infra note 33 .

12. See infra note 18 and accompanying text.

13. See Ayres \& Gertner, supra note 4.

14. 15 U.S. (2 Wheat) 178 (1817).

15. See generally E. FARNSWORTH, CONTRACTS, $\S 12.18$, at 895-904 (1982). 
Hadley's place in the larger attempt to "explain" the common law from an economic point of view.

\section{THE EFFICIENCY OF HADLEY}

In Hadley, a gristmiller contracted to have a carrier transport the broken crankshaft of the steam engine which drove the mill to be duplicated and replaced. Delivery was delayed by several days, during which time the mill could not operate, and the miller sued for lost profits during the period of delay. On appeal, the miller was denied recovery for lost profits as consequential damages. The court held that consequential loss was recoverable only if it was "such as may reasonably be supposed to have been in the contemplation of both parties, at the time they made the contract as the probable result of the breach of it."16 Apparently the court in Hadley decided that lost profits were not "in the contemplation of both parties" as a consequence of breach because normally the miller would have had a spare on hand or perhaps been shut down for other reasons in any event. ${ }^{17}$

The holding in Hadley clearly had the potential to become a very restrictive rule, under which, in Justice Holmes' interpretation, "the extent of liability ... should be worked out on terms which it may fairly be presumed (the defendant) would have assented to if they had been presented to his mind."18 Instead, the test which Hadley apparently rejected ${ }^{19}$ has become the general rule: the defendant who breaches is liable for all losses that he had "reason to foresee as a probable result of the breach when the contract was made." ${ }^{20}$ The defendant need not have tacitly assumed liability to that extent. All that matters is that he had knowledge which would make such losses foreseeable. ${ }^{21}$

\section{A. Hadley and the Information-Forcing Paradigm}

As Judge Posner casts it, Hadley stands for the principle "that if a risk of loss is known to only one party to the contract, the other party is not liable for the loss if it occurs." ${ }^{22} \mathrm{He}$ explains this principle as inducing the party with knowledge of the risk either to take precaution or reveal the risk to the other party and pay him to assume it. Posner recognizes that it is at best misleading to call this general principle a foreseeability limitation, since even though one party knows what his specific loss will be, the other knows at least that such

16. 9 Ex. at 354,156 Eng. Rep. at 151. This discussion of the facts and holding in Hadley is drawn from E. FARNSWORTH, supra note 15, at 873-74 (1982).

17. See id.

18. Globe Refining Co. v. Landa Cotton Oil Co., 190 U.S. 540, 543 (1903).

19. See Epstein, supra note 10, at 122-24.

20. RESTATEMENT (SECOND) OF CONTRACTS § 351 (1980).

21. See E. FARNSWORTH, supra note 15, at 875; Epstein, supra note 10, at 124-25.

22. R. POSNER, ECONOMIC ANALYSIS OF LAW 114-15 (3d ed. 1986). 
a loss might occur, even though his information as to its size is not as good. Posner thus analogizes this principle to the tort law "avoidability" limitation. ${ }^{23}$ The principle applies, according to Posner, to consequential damages other than lost profits. $^{24}$

The basic notion that Hadley is efficient because it forces the revelation of private information regarding consequential loss and thereby facilitates optimal precautions against breach is now the established economic understanding. I will refer to this as the "information-forcing" theory or paradigm. ${ }^{25}$ This understanding has recently been clarified and formalized by Ian Ayres and Robert Gertner, ${ }^{26}$ and by Lucien Bebchuk and Steven Shavell. ${ }^{27}$ These papers find conditions under which only an avoidability limitation is consistent with efficiency, because information revelation will not occur if this limitation is withdrawn. It is important to understand both the intuition and the assumptions

23. Posner prefers to state the Hadley principle in terms of the promisee's ability to avoid the consequences of breach, so that rather than forcing information to be revealed, the Hadley limitation on the recovery of consequential loss forces the promisee to take precautions against breach. If the promisee is indeed the cheapest cost avoider, then this would be the efficient resuit, and the Hadley limitation would not present the strategic problems with which I am concerned. Of course, Posner does not really argue that the typical case is one in which the promisee knows that he is the cheapest cost avoider. His general defense of the Hadley principle is that it "induces the party with knowledge of the risk either to take appropriate precautions himself, or, if he believes that the other party might be the more efficient preventer or spreader (insurer) of the loss, to reveal the risk to that party and pay him to assume it." Id. at 114 (emphasis added). This is a nifty bit of rhetoric: Posner wants the reader to think of the principle as an avoidability principle because this label suggests the only case in which the principle is clearly efficient.

24. Posner says that the rule of Hadley is not applied where what is unforeseeable is the other party's lost profit on the deal. Id. at 115 . He explains that:

[A]ny other rule would make it difficult for a good bargainer to collect damages unless before the contract was signed he had made disclosures that would reduce the advantage of being a good bargainer-disclosures that would prevent the [promisee] from appropriating the gains

from his efforts to identify a resource that was undervalued in its present use. This is just the application of Laidlaw $v$. Organ in a damage setting.

Id. In this passage, Posner recognizes the sort of strategic problem that I focus on here, but he does not provide any reason for thinking that the problem is present only in cases where the consequential loss is the direct lost profit on the deal.

25. This idea appears not only in Judge Posner's treatise, but in a number of other important discussions of the efficiency of contract damages rules. See, e.g., R. COOTER \& T. ULEN, LAW AND ECONOMICs 427-28 (1988); Barton, The Economic Basis of Damages for Breach of Contract, 1 J. LEGAL STUD. 277, 296 (1972); Bishop, The Contract-Tort Boundary and the Economics of Insurance, 12 J. LEGAL. STUD. 241 (1983); Perloff, Breach of Contract and the Foreseeability Doctrine of Hadley v. Baxendale, 10 J. LEGAL STUD. 39 (1981). The idea permeates even more traditional, doctrinal discussions of Hadley. See, e.g., CONTRACT LAW TODAY: ANGLO-FRENCH COMPARISONS 292 (D. Harris \& D. Tallon eds. 1989) (Hadley principle provides an "incentive for parties to exchange information at the time of negotiating the contract and hence to allocate risks .... [A] party who wishes protection for special losses ... may have to pay an increased price for the promisor to assume the additional burden."). And, largely through Judge Posner's opinions, this is becoming the explicit judicial rationale for applying the Hadley principle in a wide variety of settings. See, e.g., Rardin v. T\&D Mach. Handling, Inc., 890 F.2d 24 (7th Cir. 1989); Afram Export Corp. v. Metallurgiki Halyps, S.A., 772 F.2d 1358 (7th Cir. 1985); EVRA Corp. v. Swiss Bank Corp., 673 F.2d 951 (7th Cir. 1982).

26. Ayres \& Gertner, supra note 4. This Article deals with a number of other issues raised by what I call below the Coasean Contractual Theory, but its central section, entitled "A General Theory of Default Choice," focuses on the Hadley scenario.

27. L. Bebchuck \& S. Shavell, Information and the Scope of Liability for Breach of Contract (unpublished manuscript available at Harvard Law School, April 1989). 
that underlie these results, because my analysis, which develops the opposite intuition, follows from varying the assumptions made by Ayres and Gertner and by Bebchuck and Shavell.

In the initial, default situation under an avoidability limitation, cost minimizing carriers in our Hadley example (and promisors more generally) will take a level of precautions against breach which is efficient, given that their liability is limited to typical items of consequential loss that are known to both the carrier and the shipper. If this is all that the carrier knows-that he may be liable for consequential damages up to this limit-then the carrier will take precautions that are optimal given expected liability under that ceiling. These precautions will be too low for some shippers (those with atypically large losses) and too high for others (those with atypically small losses). There are therefore gains to be realized from trade in what is, after all, a private good, i.e., the shipper's knowledge of her actual consequential loss.

Both the shipper and carrier can benefit if the shipper reveals the magnitude of her loss. If a low loss shipper reveals that she is a low loss type by, say, requesting a low liquidated consequential damage contract, then the carrier will take fewer precautions than in the initial, default situation, but also charge a lower price. Such a contract makes a low loss shipper better off, because she does not need higher precautions to be taken. Conversely, if a high loss shipper reveals that she is a high loss type and requests a high liquidated consequential damage contract, then the carrier will take more precautions, but also charge a higher price. There clearly exist prices at which a high loss shipper is better off with this contract, however, because when the carrier is liable for higher damages he takes precautions which are closer to the optimal level of precautions against a risk of high loss.

This is the story under a Hadley-type limitation. It is an elaboration of Posner's information-forcing paradigm. Most significant about the recent work by Ayres and Gertner and by Bebchuck and Shavell, however, is the next step in the analysis-the demonstration that information will not be revealed if we begin with a legal default rule of relatively unlimited liability, such as the foreseeability rule. To see why, consider the initial position of a high loss shipper under an expansive default liability rule. This shipper is fully covered against her loss. The probability of breach and consequential loss are in fact too high for this shipper, because the carrier bases his precautions on the average or expected loss under the expansive default, which is by definition less than that suffered by the high loss shipper. But there is no reason for the shipper to care about the probability of loss if she is fully covered against loss. Hence, the shipper has no incentive either to propose or to agree to a deviation 
from the status quo of unlimited liability. The high loss shipper's private information is left untraded. ${ }^{28}$

The same reasoning, however, implies that the low loss shipper should have an incentive to tell the carrier that she does not want the high-price expansive liability contract. The low value shipper would propose or accept a contract with limited liability and a lower price.

Neither Ayres and Gertner nor Bebchuck and Shavell deny this. They recognize the incentive that low value shippers have to bargain around the expansive liability default rule, but make formal (i.e., mathematical) assumptions about the relative probabilities of low and high value shippers which make it unlikely that society will be best off under the expansive liability default. Ayres and Gertner argue that as the probability that any given shipper will suffer high consequential losses goes to zero, low value shippers will lose any incentive to bargain around the expansive liability default, no matter how small the transaction cost involved may be, because the contract is converging to what is optimal for such a shipper. But this just says that if there is only one kind of shipper, who suffers low loss, then an expansive liability contract is essentially identical to a limited liability contract, so there is nothing to gain by bargaining around an expansive liability default. ${ }^{29}$ Conversely, a high value shipper will realize a fixed gain by bargaining around a default which provides only for low carrier liability, because the contract's liability coverage does not depend on the relative proportion of low and high value shippers.

Somewhat similarly but more simply, Bebchuck and Shavell argue that if low value shippers outnumber high value shippers, and positive transaction costs are incurred in bargaining around the default, then transaction costs will be lower if the default calls for limited liability and forces high value shippers to bargain than if it calls for expansive liability and forces low value shippers to bargain. ${ }^{30}$

\section{B. Hadley and Coasean Contractual Theory}

The central contribution made by Ayres and Gertner is not their analysis of the Hadley information-forcing theory (which, as I noted above, has been the accepted view for several years), but rather the recognition that this theory may significantly qualify what I shall call the "Coasean Contractual Theory." This qualification calls attention to the importance of strategic incentives in bargaining around initial or "default" legal rules. To see why these strategic

28. Both the shipper and carrier benefit if a high value shipper reveals this fact, however, and thus if such a revelation could be verified, the carrier might actually offer a discount to a high value shipper who revealed this fact and thereby allowed the carrier to take optimal precautions. Below, I note that liquidated damage doctrine can perhaps be looked at as an attempt to provide such verification and thereby promote such beneficial exchanges of information.

29. Ayres \& Gertner, supra note 4, at 110-11.

30. L. Bebchuck \& S. Shavell, supra note 27. 
incentives are important to the Coasean Theory, a brief summary of that theory is in order.

Coase's Theorem maintains that under certain assumptions, including the assumption of zero transaction costs, initial legal rules or entitlements- "default" rules-are irrelevant to the attainment of efficient outcomes through private bargaining. ${ }^{31}$ The Coasean Contractual Theory is built upon an immediate corollary obtained by relaxing Coase's assumption of zero transaction costs. The corollary has two parts: first, if the gains from bargaining around the status quo entitlements fixed by the law fail to exceed the cost of bargaining, then the initial entitlement is also the final entitlement; second, if transaction costs are positive but less than the gain from bargaining to a new allocation, then the initial entitlement still matters because it determines who will bargain and at what cost. When individuals have differing preferences, the Coase Theorem has been taken to prescribe the selection of an initial entitlement which is efficient for "most" bargainers, since this is the entitlement which will minimize transaction costs. ${ }^{32} \mathrm{~A}$ common complementary final step in the Coasean analysis is to observe what most bargainers agree upon and set the initial or status quo entitlement at that point. ${ }^{33}$

This all presumes, of course, that individuals are free to bargain around the legal rule-that the legal rule merely supplements other terms of the parties' agreement and does not mandate that a particular term be included. Indeed, Coasean contractual analysis is inconsistent with mandatory legal rules, since if the gains from contracting around a legal rule outweigh the transaction costs of doing so, then such a move is efficient and ought to be allowed. Rather than mandating a final outcome, the law on this view merely adopts a standard (or default) term which parties are free to alter. ${ }^{34}$

Taken within the context of this larger theory, what Judge Posner calls the Hadley avoidability limitation superficially seems to be a Coasean solution. If the parties do nothing to alter the default outcome under Hadley, then the measure of consequential damages in their contract will be that which is appropriate in the typical or average transaction. Hadley may thus be viewed

31. Coase, supra note 8 . Coase's hypothesis has largely been supported in experimental tests. See, e.g., Hoffman \& Spitzer, The Coase Theorem: Some Experimental Tests, 25 J.L. \& ECON. 73 (1982). But see Donohue, Diverting the Coasean River: Incentive Schemes to Reduce Unemployment Spells, 99 YALE L.J. 549 (1989); Schwab, A Coasean Experiment on Contract Presumptions, 17 J. LEGAL STUD. 237 (1988).

32. For a lucid statement of this theory, see M. POLINSKY, AN INTRODUCTION TO LAW AND ECONOMICS 11-14 (2d ed. 1989).

33. I discuss the validity of this empirical inference at greater length. See infra, at Part III.B. Authors applying the Coasean Theory to analyze the corporate law as a standard form contract rely particularly heavily on this empirical inference. See, e.g., Carlton \& Fischel, The Regulation of Insider Trading, 35 STAN. L. REV. 857 (1983) (arguing that failure to find corporate charters outlawing insider trading suggests such trading is efficient).

34. On mandatory versus suppletory contract terms, compare Coffee, The Mandatory/Enabling Balance in Corporase Law: An Essay on the Judicial Role, 89 CoLUM. L. REV. 118 (1989) and Gordon, The Mandatory Structure of Corporate Law, 89 CoLUM. L. REV. 1549 (1989) with Easterbrook \& Fischel, The Corporate Contract, 89 COLUM. L. REV. 1416 (1989). 
as supplying the rule which most parties would want, and which therefore minimizes the transaction costs incurred by those who bargain around the rule.

As Ayres and Gertner have pointed out, however, the standard Coasean theory does not explain Hadley, and this shows that the prescription to minimize transaction costs by choosing as the default that rule which "most" parties would want is not always enough to generate efficient outcomes. What the standard Coasean prescription generally neglects is precisely what Posner, Ayres and Gertner, and Bebchuck and Shavell stress is Hadley's efficiency: its impact in creating incentives for information revelation through bargaining. ${ }^{35}$ If Hadley does not create these incentives-if a high loss promisee fails to disclose her private information about loss to the promisor-then the promisor cannot take optimal precautions against breach, and a limitation may create large inefficiencies. Thus, as a general matter, it is not always enough to ask what most parties would want and then to set the initial legal default rule at this point. The selection of a default rule necessarily determines the strategic incentive to bargain around the default, because the default dictates what kind of private information will be revealed in bargaining around it. The standard prescription for choosing default rules must be qualified to take into account the fact that information is revealed in bargaining around the default. ${ }^{36}$

Ayres and Gertner make a major contribution in recognizing how the general problem of information revelation, a problem which is of central importance in contemporary game theory, ${ }^{37}$ applies to the selection of a contract default rule. However, the Ayres and Gertner conclusion-that if information revelation concerns argue for something other than the standard choosewhat-most-parties-want Coasean prescription, then those concerns argue in favor of information-forcing default rules such as the restrictive Hadley avoidability default-is strongly dependent upon special underlying assumptions. These assumptions limit the generality of their results, so that those results say little about the effect of strategic bargaining in general. In particular, like Bebchuck and Shavell, Ayres and Gertner assume that carriers in the Hadley story are identical price-taking firms. This means that a carrier is interested in learning

35. See Ayres \& Gertner, supra note 4, at 91.

36. Id. at 94 . The information revelation phenomenon may operate somewhat differently in the context of relational contracts defining corporations, partnerships, and marriages as opposed to the one-shot, discrete transaction I consider in this Article. For a non-cooperative game-theoretic approach to information revelation and implied contractual terms in cooperative ventures, see J. Johnston, Opting In and Opting Out: Bargaining for Fiduciary Duties in Cooperative Ventures (unpublished manuscript available at Vanderbilt Law School, Sept. 1990). For an interesting attempt to explain and justify commercial default rules as the product of limited judicial competence and norms of social cooperation, see Scott, A Relational Theory of Default Rules for Commercial Contracts, 19 J. LEGAL STUD. 597 (1990).

37. For some illustrations which show how information revelation cuts across many contemporary approaches to incentive problems, see E. Maskin \& J. Tirole, Principals with Private Information I (Independent Values) and II (Dependent Values) (Harvard Institute for Economic Research Discussion Papers Nos. 1234 \& 1412) (principal-agent framework); Myerson, Mechanism Design by an Informed Principal, 51 ECONOMETRICA 1767 (1983) (mechanism design); Okuno-Fujiwara, Postlewaite \& Suzumura, Strategic Information Revelation, 57 REV. ECON. STUD. 25 (1990) (extensive form games with sequential equilibria). 
what the shipper's actual damages from breach will be not in order to compute his most profitable price, but only in order to take the appropriate level of precautions against breach. And there is nothing for the shipper to learn about the carrier, since all carriers are identical.

This is a far cry from what is colloquially called "bargaining." 38 In the carrier-shipper example, we might more naturally think of bargaining as involving a series of assertions, bluffs, offers, and counteroffers, as the carrier tries to figure out exactly how much he can charge the shipper without losing the deal, and the shipper attempts to get an idea of how reliable the carrier is and how much it really costs her to deliver on time. When Ayres and Gertner say that information revelation issues argue for "penalty" or information-forcing default rules, therefore, they are making a statement about information revelation issues in the austere world of my previous paragraph, not this strategically richer, more intuitive story of haggling and rent seeking.

\section{StRategic Information Revelation AND the Choice of Default RULE}

My goal in this Part is to use the stylized shipper-carrier bilateral bargaining problem presented by Hadley to develop some general points about information revelation in bargaining around the law. I will begin with a very simple model, and successively add to the model's complexity. In this way, the complexity of the information revelation problem-its sensitivity to the kinds of assumptions one makes about the underlying bargaining process-will become apparent. This progression through alternative theoretical scenarios will also show that the strategic incentives in bargaining around a default rule of limited liability often go the "wrong" way-that is, they discourage such bargaining-whereas incentives in bargaining around an expansive default rule usually go the right way.

Before beginning the story-telling, however, two clarifications are necessary. The first is terminological and conceptual: I will refer throughout this part to two types of default rules in the Hadley situation, "limited" and "unlimited" liability rules. By "unlimited," I mean (and, in the Appendices, formally model)

38. It also differs dramatically from what is meant by "bargaining" in the technical game-theoretic literature. This usually supposes that the parties bargain over positive economic rents. See, e.g., Cramton, Sequential Bargaining Mechanisms, in GAME THEORETIC MODELS OF BARGAINING 149 (A. Roth ed. 1985). Some recent articles have explored how a competitive outcome might come about through decentralized trade or bargaining. These tend to suppose that traders randomly meet and then engage in some form of strategic bargaining, which is given a particular extensive form. Interestingly, it turns out that even with frictionless trading - no time or other costs-noncompetitive equilibria can only be ruled out by assuming that traders do not observe the offers other people exchange, but know only their own histories and whom they can bargain with in the future. This resuit is established in Rubinstein \& Wolinsky, Decentralized Trading, Strategic Behavior and the Walrasian Outcome, 57 REV. ECON. STUD. 63 (1990), which contains citations to the related literature. Thus, while it would be incorrect to say that bargaining and competition are incompatible, it has not yet been shown that they are compatible except under rather restrictive assumptions. 
a rule which allows all consequential damages to be recoverable, but I assume that there is a finite limit to such damages which is known by the carrier. Thus, what I call an "unlimited" liability default is more akin to an expansively interpreted, open-ended "foreseeability" default rule than to a rule which provides additionally for the recoverability of "unforeseeable" damages. There are no "unforeseeable" damages in my model, for the reason that I am interested in comparing an expansive foreseeability default rule-the rule which Hadley has become-to a narrow default rule like the "avoidability" rule Hadley represents in Judge Posner's treatise.

The second item to clarify at the outset is an assumption which I shall maintain throughout the analysis, except where it is explicitly relaxed. I assume that the only obstacle to transacting around the default is the potential strategic loss in revealing private information, and therefore that conventional or direct transaction costs are minimal. This unconventional assumption is not as farfetched as it might seem. In all of my scenarios, bargaining around the law means including what is essentially a short liquidated damage clause akin to clauses in household moving contracts or the Federal Express contract which simply varies the contract price with the extent of liability assumed by the carrier. There may be costs in determining what price to charge for varying amounts of liability, but these are essentially the same costs incurred in determining what price to charge given the default level of liability.

I argue here for the plausibility of this assumption simply to clarify the difference between the kind of "cost" I am considering-strategic information revelation - and what is usually meant by transaction cost. In any event, I will bring these typical transaction costs back into the analysis before concluding, because it is possible (although as I shall argue unlikely) that they would alter the choice between competing default rules.

\section{A. Single Price Contracts ${ }^{39}$}

We consider first a model in which a carrier with some power over price is constrained to offer a single level of coverage against shippers' consequential loss, either unlimited, or limited by the upper bound of "foreseeable" consequential loss. I will assume that the carrier's care level, and hence probability of failing to deliver, is fixed and does not vary with the level of loss coverage he provides. This assumption of fixed care can be justified by thinking of the carrier as putting all shippers' goods into a single cargo hold, with a standardized workforce and vessel and general method of operation leading to a stan-

39. See infra Appendix A. As with other sections in this part, the verbal argument in the main text is supplemented by a corresponding Appendix which demonstrates the main textual assertion in a more precise mathematical framework so that the interested reader can verify my claims. References to the technical literature which is related to my argument in each section are also contained in the technical appendices. This section is supplemented by Appendix $A$. 
dardized probability of misdelivery. Later subsections will consider the consequences of relaxing all of these admittedly rather austere assumptions.

To analyze incentives to deviate from alternative legal default rules, we need first to solve for the price that obtains under each default. To this end, assume that bargaining is characterized by the carrier making a single take-it-orleave-it offer to the shipper. In such a simple bargaining game, the carrier will choose a price to maximize his expected return. As the carrier increases the price, the carrier must balance the decrease in the probability of acceptance and increase in expected liability given breach against the increase in revenues.

As I have formulated it, this bargaining game is very favorable to the carrier, who gets to make the take-it-or-leave-it offer. However, of course the carrier's best offer in general varies with the extent of his liability for breach if his offer is accepted and a contract is formed. When liability is unlimited (and extends up to the maximum shipper consequential loss) the carrier will charge a very high price, because he must take into account his expected liability, given that the contract is accepted. The carrier's optimal price will be much lower when the default rule specifies limited liability, because expected carrier liability given acceptance of the contract offer is much lower under limited liability.

In analyzing the strategic incentives to bargain around these default rules, it is important to recognize two properties possessed by the carrier's optimal, expected profit-maximizing default price. Such a price is defined by a marginal condition which says that the benefit from any further increase in the offer price-the increase in net revenue if the offer is accepted-is outweighed by the cost from a further increase in offer price-the decrease in the probability of acceptance, multiplied by the (given) price. Because the carrier's best take-itor-leave-it offer is defined in this way, his offer price is inefficiently high, and yet yields positive rents, or profits, for those shippers who accept. The price is inefficiently high because it exceeds the carrier's costs. ${ }^{40}$ It is determined not by the carrier's costs, but by his beliefs about how much the shipper will be willing to pay. Nonetheless, a shipper will not accept unless she can do at least as well by accepting than by not, and this ensures that any shipper who accepts will earn positive rents. In particular, shippers with very high value from the contract will earn the highest rents. Because the carrier does not know the shipper's actual value, he cannot extract all of the value through the price he charges.

These general points are true regardless of whether we begin from a limited liability default or from an unlimited liability default. However, the probability of agreement and expected carrier profit given agreement are not the same under these alternative default rules. Therefore, the carrier's incentive to bargain

40. This assumes that the distribution of shipper values is such that some shippers have a value from performance that exceeds the carrier's cost, so that a price in excess of cost will generally be optimal. 
around the default depends upon the default. More specifically, as explained below, for some distributions of shipper value, there may be no incentive for the carrier to increase his liability above the limited default, whereas there will always be an incentive for the carrier to propose or agree that carrier liability be reduced from an unlimited default.

Suppose first that the shipper approaches the carrier, simply tells the carrier what his damages will be, and asks for coverage in this amount. If a simple message of this sort is credible, however, then a high value shipper who would have contracted under the default rule will not send the message. This is because under either default rule, high value shippers who contract do so because they earn positive informational rents-rents which accrue to the shipper's private information about her actual consequential loss in the event of breach. For a shipper who values performance highly (i.e., suffers a large loss in the event of breach), and accepts the high-priced unlimited liability default contract, there is obviously no incentive to reveal her value when the default already provides for unlimited liability because she is already fully covered. Such a shipper also has no incentive to reveal her value when the default provides only limited liability, because if the revelation is credible and fully informs the carrier as to the shipper's value, the carrier will extract all of this value by making a take-it-or-leave-it offer of full coverage at a price precisely equal to carrier value. ${ }^{41}$ Rather than earning positive informational rents, the shipper will be forced to accept a zero rent contract. Anticipating such a response, the high value shipper would be foolish simply to tell the carrier what her value is.

Low value shippers, however, will generally be better off if they tell the carrier that they have low value and want a cheaper contract. If the shipper's value from the contract is low enough, then she will not accept the carrier's default offer, especially when the default rule provides for unlimited carrier liability, and induces the carrier to set a very high price. ${ }^{42}$ Because she does not accept the default contract, such a shipper starts out earning zero rents in the default position. If she could credibly communicate to the carrier that her value really is low and she will not contract at the default price, then the shipper would be no worse off and the carrier better off if they contracted around the default. The carrier could offer a low liability, low price contract which the low value shipper would accept.

41. A similar point has recently been made by Louis Wolcher. See Wolcher, Price Discrimination and Inefficient Risk Allocation Under the Rule of Hadley v. Baxendale, 12 RES. L. \& ECON. 9 (1989). WoIcher's treatment assumes, as do $I$ in this Section, that the carrier offers a simple single price contract under the default (i.e., the carrier initially does not discriminate in price). His analysis basically stops at this point, however, and he therefore does not consider the issues that I discuss in the remainder of this Part of the Article.

42. This is true under both the unlimited and limited liability default, because as I have defined it, the limited liability default caps damages at the level of expected damage, and therefore some shippers will in fact suffer less damage than the average and will be unwilling to accept a contract whose price is based on this level of liability. 
Thus, if we restrict attention only to truthful messages by shippers about their value from contracting, it is clear that in this model, the only such messages which will be effective in bargaining around the default are messages from low value shippers, sent to get a lower liability limit than the default provides. That is, if truthful and fully informative messages about shipper value are the only way the parties can communicate to bargain around the default, then the parties will not bargain around a limited liability default such as the Hadley avoidability limitation, but will bargain around an expansive default.

It would clearly be wrong to assume, however, that bargaining around the default requires that the shipper fully inform the carrier as to her value from successful performance (and loss from carrier breach). The shipper might send a less than fully informative message which is nonetheless effective in getting the carrier to offer something other than the default contract. Or it may be that the shipper does not have to send a message at all: the carrier may propose an alternative to the default contract, which the shipper is free to accept or reject. But even allowing for the possibility that the shipper sends a fuzzy message, or that the carrier makes the proposal, the strategic obstacles to bargaining around the limited liability default remain more serious than the obstacles to bargaining around the unlimited liability default.

Consider the strategic incentive to bargain around limited liability. If a carrier says that his value is so low that he cannot profitably contract given the limited liability default price, then it must also be true that he would not contract given a higher, unlimited liability default. Thus, if such a statement is true given a limited liability default, then it must also be true given an unlimited liability default. As for the position of a high value shipper, in contrast, it is possible that such a shipper would prefer that carrier liability be unlimited. Such a shipper might have an incentive to send a fuzzy message indicating that she would like to be offered an unlimited liability contract, which the shipper might well accept if priced favorably.

But in the present model, with fixed carrier precautions and risk neutrality, movement to the unlimited liability contract does not bring any benefit from improved risk sharing or improved precautions. Rather, the shipper benefits only because she pays an increased price which is less than the reduction in her expected uncompensated loss. And the carrier benefits only because the price increase is greater than the increase in his expected liability. The difficulty confronting the parties in trying to bargain to such an unlimited liability contract is informational. Shippers with the highest value will have the strongest incentive to opt for the alternative unlimited liability contract over the original default, limited liability contract. The carrier should realize that the default contract has this effect, and accordingly price the unlimited liability contract at a very high level. But the carrier's decision whether to offer such an unlimited liability contract must now be based on his expected profit from such a contract, relative not to the alternative of no contract, but to its level of expected 
profit under the default. Any shipper who accepts the unlimited liability alternative would accept the limited liability alternative, so by offering the alternative, the carrier is not increasing the probability of reaching an agreement. Therefore, for the carrier to have an incentive to offer the unlimited liability alternative, he must be able to charge a much higher price for the alternative than for the default contract. But high value shippers already accept the default, and thus will not accept as high a price for unlimited liability as they would were the "default" position no contract at all. For some distributions of shipper value, these scissoring incentive effects of the initial, default contract imply that there is no mutually beneficial unlimited liability alternative.

This sort of problem does not afflict bargaining around the alternative, unlimited liability default. The contract price under this damage default rule is very high, and because it is so high, there is a relatively low probability that a shipper will accept. By offering a limited liability, low price alternative, the carrier loses some expected profit on deals he would have made anyway, i.e., deals with shippers who would have contracted even given the high price. But the carrier greatly increases his probability of reaching an agreement in the first place, by offering a limited liability, lower priced alternative which will be accepted by low value shippers who really would not have contracted at the unlimited liability default price. Put somewhat differently, the carrier is better off acceding to a shipper message of the sort "I won't contract unless you offer me a low liability, low price alternative" even if he knows that the message is not fully credible. The problem with the alternative message "I won't contract unless you offer me an unlimited liability, high price contract"-a message sent to induce bargaining around the limited liability default-is that it must be false. The carrier does not increase the probability of a deal by offering a high price, high liability alternative in addition to the low price, limited liability default, whereas he does do so by offering a low price, limited liability alternative in addition to the high price, unlimited liability default. For this basic reason, there may be an incentive to bargain down from the unlimited liability default even when there is no incentive to bargain up from a limited liability default.

\section{B. Extensions to the Model: Relaxing the Assumptions to Add Reality and Robustness}

The model in the previous Section is built upon a set of quite restrictive assumptions. The narrowness of my assumptions provides an easy avenue to criticize, and dismiss as artifactual, the results presented. To avoid these objections, and to add relevance and increased reality to my analysis of the information revelation problem, this Section explores the consequences of relaxing each of the assumptions maintained thus far. 


\section{Single Price Contracts with Variable Carrier Precautions and Two- Sided Private Information ${ }^{43}$}

An obvious limitation on the analysis thus far is that by assuming that carrier precautions are fixed and do not vary with the extent of possible carrier liability, I have failed to capture what is usually viewed as the primary efficiency in a limited liability default rule: the rule's ability to force shippers to reveal special consequential loss, which then allows carriers to take the optimal, fullinformation level of precautions against breach. In this Section, I capture this important social benefit from information transmission by assuming that the carrier optimally adjusts the precautions against breach in light of his expected liability. An immediate and obvious consequence of assuming optimal carrier precautions is that both the shipper and carrier may gain by the shipper's revelation that it has much to lose from breach and would like to contract around a limited liability default. Such a revelation allows the carrier to take the appropriate level of precautions, and makes it possible for the carrier to charge a price for the high liability contract which makes both carrier and shipper better off.

The story becomes much more complicated, and I think also more interesting and realistic, if we assume both that the carrier optimally adjusts its precautions in light of its potential liability for consequential loss, and that the shipper does not know the actual probability of carrier breach. That is, I will assume that the carrier knows his breach probability, but the shipper has only a set of subjective probabilities over possible values of this probability and does not know the true value.

With these altered assumptions, we have made strategic revelation of the shipper's value somewhat less problematic, but created a strategic information revelation problem for the carrier where none existed. The shipper's problem is less acute, because as just pointed out, when the shipper reveals her private information regarding the value of performance, she can realize a benefit from increased carrier precautions against breach. The problem, though, is that the size of this marginal benefit depends upon the carrier's breach probability, and this is not precisely known by the shipper. The shipper's imperfect information about the carrier's breach probability is likely to create a strategic obstacle to bargaining around (up from) the limited liability default.

To see this most easily, suppose that the shipper believes that the carrier is very efficient and reliable, and in fact thinks that there is a very low probability of breach even when carrier liability is limited (and the optimal level of carrier precautions against breach is therefore relatively low). Since the shipper perceives a low default probability of breach, even a shipper who will lose unusually large profits if the carrier breaches will perceive little benefit in

43. Appendix B contains the technical supplement to this Section. 
bargaining for increased carrier liability. The extent of carrier liability affects the shipper's payout only if the carrier breaches, and if the shipper thinks this probability is already low-in the limited liability default position - then increases in carrier liability will have little impact on the shipper's expected value from the contract.

Now note that the carrier will not get the contract at all unless the shipper perceives a positive expected value, and the carrier thus may have a natural incentive in persuading the shipper that he is reliable and does not often breach. But if the carrier succeeds in persuading the shipper that the default breach probability is low, then the carrier also necessarily succeeds in persuading the shipper that she probably does not stand to benefit much from bargaining for an increase in carrier liability above the limited liability default. Thus, the message which gets the carrier the default contract-a message signaling low breach probability-will, if and only if it is believed, make the shipper suspicious that the carrier's increased price for an unlimited liability contract is merely an attempt to extract informational rents. Bargaining around limited liability puts the carrier in a strategic dilemma: if he persuades the shipper that the shipper will be better off with the high price, high liability alternative, then he may also persuade the shipper that the shipper in fact is better off not contracting with him at all, because the breach probability is too high, no matter what the extent of carrier liability.

Note that I am arguing only that in persuading the shipper to accept the default contract, the carrier might cause the shipper to underestimate the probability of breach and thereby reject an efficient, high liability alternative to the default. For this reason, my results here are consistent with the argument made by Alan Schwartz, who argues that promisee mistakes in estimating the promisor's breach probability affect price but not efficiency. ${ }^{44}$ My results qualify this argument: the default contract may be Pareto superior to no contract, but inferior to a potential alternative which the parties will not reach because promisee mistakes in estimating the promisor's breach probability.

The carrier does not face such a strategic dilemma in bargaining around the unlimited liability default. A shipper will tend to prefer the cheaper limited liability contract to the more expensive unlimited liability default if she thinks that the carrier is unlikely to breach even given limited carrier liability. Conveying such information increases rather than reduces the probability of contracting with the shipper, and therefore is in the carrier's strategic interest.

44. See Schwartz, The Myth That Promisees Prefer Supracompensatory Remedies: An Analysis of Contracting for Damage Measures, 100 YALE L.J. 376 (1990). 
2. Two-Sided Asymmetric Information and Market Constraints on Bargaining: Price as a Signal of Quality

In previous Sections, I assumed that the carrier and shipper engaged in bilateral bargaining over the terms of their contract, and did not consider market constraints on these terms. It may be argued that if we view bargaining as occurring instead under the constraint imposed by a competitive carriage market, then the strategic information revelation problems which $I$ have stressed will largely disappear. As shown by Ayres and Gertner, and by Bebchuck and Shavell, however, even if the only item of private information is the shipper's loss, competition does not completely eliminate strategic information revelation problems. Competition forces carriers to set price equal to cost and prevents carriers from extracting private informational rents from shippers through the price charged, but it does not mean that a shipper has nothing to lose from information revelation. A high value shipper under a default rule of unlimited liability, for example, is fully covered and may have no incentive to reveal her value, because doing so would cause the carrier to increase his price, with no offsetting benefit to the shipper. ${ }^{45}$

This is a problem that affects markets with one-sided private information. In markets where both sides have private information-the carrier about his probability of breach, and the shipper about her loss in the event of breach-then competition is even less effective in overcoming strategic information revelation problems. In this Section, I argue that some of the most important strategic incentives in markets with such two-sided private information argue for the desirability, on information revelation grounds, of the unlimited liability default.

It may be argued that markets create a natural incentive for low breach probability carriers to identify themselves, so that competitive signaling should eliminate the informational asymmetry on the carrier's side, and return us to the Ayres and Gertner/Bebchuck and Shavell world in which the limited liability default may be preferable. Because a low breach probability may correspond to higher, more costly precautions against breach, a high quality carrier will have a low breach probability and high costs. We might then rely on a substantial body of recent theoretical work showing that if high quality

45. The carrier benefits from learning the shipper's actual loss because he can take the appropriate (higher) level of precautions. Thus, the carrier could benefit from learning the shipper's actual loss even if he kept price constant. Indeed, the carrier could offer to pay the shipper a sum equal to the decrease in carrier expected total cost made possible by the shipper's revelation and be as well off as before, with the shipper made better off. The problem, however, is that such an offer might also be attractive to low loss shippers who say that they are high loss shippers just to get the bonus payment for revealing loss information. This problem could be overcome were the shipper's stated loss subject to ex post verification. Later in the text, I develop this point, which provides an explanation for liquidated damage doctrine based on informational incentives. 
corresponds to high cost, then high quality, high cost producers may profitably separate themselves by charging a high price. ${ }^{46}$

When this analogy between a high cost, high quality goods producer and a high cost, low breach probability carrier is pursued, however, it turns out to support further my argument of the previous Section. Consideration of the carrier's signaling incentives suggests that a reliable, low breach probability carrier has a competitive advantage in offering a high liability contract to high value shippers, and a less reliable but cheaper carrier has an advantage in offering a limited liability package to low value shippers. I argued above that a high breach probability under the limited liability default makes unlimited liability more attractive to shippers. But, as I explain below, the trouble is that the kind of carrier who can truthfully say that he has a high breach probability under a limited liability default is the cheap, unreliable kind who will not get the unlimited liability contract. Or, viewed somewhat differently, the reliable, high cost carrier already signals his type under limited liability by charging a relatively high price given limited liability. Such a carrier thus does not need to bargain around limited liability to signal his type, and, moreover, would never want to say that his breach probability is high, because its competitive advantage lies in his breach probability being low.

To explain these points, assume that there are two types of carrier, as in the previous paragraph, and two types of shipper, high value and low value, and assume that shippers learn about carrier type only by observing the price charged by the carrier. ${ }^{47}$ With these assumptions, expected carrier liability under the limited liability default may be low enough so that the low breach probability carrier has higher total expected cost. That is, the expensive, high quality carrier is at a natural cost disadvantage when liability is limited: his precautions are unnecessarily high for this level of liability. But then with limited liability, the high quality, low breach probability carrier can easily signal its type by charging a high price; that is, the conditions for such signaling to occur

46. See, e.g., Milgrom \& Roberts, Price and Advertising as Signals of Product Quality, 94 J. POL. ECON. 796 (1986); K. Bagwell \& M. Riordan, High and Declining Prices Signal Product Quality (The Center for Mathematical Studies in Economics and Management Science, Northwestern University, Discussion Paper No. 808 Oct. 1988). There are other theories which explain the price-quality relationship on the basis not of cost differentials but by the presence of some informed consumers. See, e.g., Chan \& Leland, Prices and Qualities in Markets with Costly Information, 49 REV. ECON. STUD. 499 (1982); Wolinsky, Prices as Signals of Product Quality, 50 REV. ECON. STUD. 647 (1983). Finally, a related literature explores how the cost of search and consumers' propensity to shop affects the distribution of price and quality under various assumptions about market competiveness and product homogeneity. See, e.g., Schwartz \& Wilde, Imperfect Information in Markets for Contract Terms: The Examples of Warranties and Security Interests, 69 VA. L. REV. 1387 (1983); Schwartz \& Wilde, Product Quality and Imperfect Information, 52 REV. ECON. STUD. 251 (1985). For an overview of many of these related models and a demonstration that the presence of some well informed consumers cannot in general eliminate price dispersion, as some stores still take advantage of ill-informed consumers by charging high prices, see Stiglit,, Imperfect Information in the Product Market, in HANDBOOK OF INDUSTRIAL ORGANIZATION: VOLUME I 769 (R. Schmalensee \& R. Willig eds. 1989).

47. That is, shippers are uninformed and become informed only by updating their beliefs on the basis of what they learn from the carrier's price. 
in equilibrium hold. The high quality, low breach probability carrier does not need to bargain around the damage default rule in order to signal his type.

Suppose, by contrast, that the default rule provides unlimited liability. If this default leads to much higher expected liability than the limited liability default ${ }^{48}$ then the high quality, high cost carrier is the more efficient carrier under this default. This is because his relative cost advantage is greater, the higher the level of expected liability and (optimal) precautions. Thus, such a reliable but expensive carrier could charge a price under the unlimited liability default which was lower than the lowest price consistent with non-negative profits for the unreliable carrier. But then the reliable, high quality carrier would be taking all the business under the limited liability default, and the unreliable low quality carrier would have a strong incentive to distinguish himself by offering a limited liability alternative, an alternative for which he has a cost advantage and which will attract low value shippers. ${ }^{49}$

Thus, the unlimited liability default may force low quality, low cost carriers to signal their type of offering under the limited liability alternative, whereas high quality, high cost carriers naturally signal their type under the limited liability default. Moreover, signaling incentives are actually at odds with the information-forcing theory of limited liability. If there were only one type of carrier, then a shipper would be more likely to prefer unlimited liability, the higher the carrier's probability of breach. But with two types of carrier, a carrier with a high probability of breach under the limited liability default is precisely the sort of carrier which a high value shipper wishes to avoid. Such a carrier would be revealing something only so that the recipient of the revelation would contract with someone else, and without any need to do so, because high quality carriers might well already charge an informative price leading to the same sort of separation between shippers.

\section{Price-Liability Menus ${ }^{50}$}

Previous Sections have assumed that the carrier simply offers a single price given the liability limit provided by the default rule. However, if a carrier has some market power-that is, some ability to set his price according to the shipper's value from the contract and willingness to pay-then the carrier could generally do better than a single price contract allows. The carrier could offer a menu of contracts, which vary by charging a different price for different levels of carrier liability for consequential damages. Such a menu would be designed to induce shippers to reveal their true value from the contract, and thus extract as much value as is consistent with two constraints: first, that the shipper be at least as well off contracting as not, and second, that the shipper

\footnotetext{
48. That is, if there are some shippers whose damages exceed the limited liability ceiling.

49. Appendix $\mathrm{C}$ develops this model more rigorously.

50. Appendix D provides a technical demonstration of the points made in this Section.
} 
in fact reveal her true value from the contract through her choice from the contractual menu..$^{51}$

Such a menu thus is designed to induce the revelation of private information, and therefore the more complicated form of private contract might seem to make information revelation in bargaining around a default rule of little or no interest. My purpose in this Section is to explain instead how strategic problems in bargaining around the default may be severe even with these more complicated private contracts. My argument here is, however, somewhat different than those made in previous Sections: when the carrier offers a rentextracting menu of contracts, strategic behavior may preclude bargaining around either default rule.

Note first that by offering a menu of contracts in which price varies with the extent of its liability for consequential damages, a carrier can discriminate among shippers, based on shippers' value from and willingness to pay for the contract. In offering such a menu, the carrier faces the strategic problem of getting the most out of each type of shipper. In particular, the carrier must be concerned that a shipper with high value from the contract might choose not the high price, high liability contract which the carrier would like to see her choose, but instead a cheaper, less profitable contract which is intended to attract the low value shipper. To create a disincentive for high value shippers to defect to the cheaper contract, the carrier will in general want to degrade the cheap contract, to offer, for example, less than full insurance against consequential loss for a low price, while at the same time offering full insurance against consequential loss at a higher price.

If the default rule provides for unlimited liability, then it will not in any way impede the carrier in setting the optimal menu of contracts. Assuming a simple world of two shipper types, high value and low value, there are essentially two types of cases to consider. First, if the proportion of low value shippers is not too low, then the carrier will offer a two-contract menu: an expensive full liability contract and an inexpensive limited liability contract. Such a contract gives zero rents to the low value shipper, but must give positive rents to the high value shipper, that is, the high value shipper could pay more than the carrier charges for the full liability contract and still earn a positive return. The high value shipper must earn positive rents, for she can always do so by opting for the low liability/low price contract. (This follows immediately from the fact that this contract gives the low value shipper zero rents). But then

51. These two constraints are known in the technical literature respectively as the individual rationality constraint and the incentive compatibility constraint. They are general constraints in incentive problems under incomplete information, problems where the goal is to motivate an agent to make a choice the desirability of which depends upon information which is known only to the agent. Generally, the need to induce the agent to reveal his private information makes it impossible to induce the agent also to choose the action which society (or, more generally, the principal) would prefer most given that information. For some illustrations of these sorts of problems, see J. LAFFONT, FUNDAMENTALS OF PUBLIC ECONOMICS (J. Bonin \& H. Bonin trans. 1988); E. RASMUSEN, supra note 5, at Part II. 
in this situation - where the carrier offers a two-contract menu giving the high value shipper positive rents-the high value shipper would never simply reveal her value, for the same reason given earlier: such revelation would simply enable the carrier to offer the high value shipper only a contract which completely extracts the shipper's rents.

The other important type of case occurs when the probability of a low value shipper is so low that the carrier is better off not offering a contract which the low value shipper will accept. Because there is a low probability of a low value shipper, the carrier willingly sacrifices profits on contracts with low value shippers in order to extract all of the high value shippers' rents, some of which could not be extracted if high value shippers had the option of opting for a cheap, limited liability package.

If this is indeed the optimal strategy for the carrier to pursue under the unlimited liability default, then both high value and low value shippers would be better off with limited carrier liability. If the carrier was prohibited from agreeing to take on more than a specified level of liability and the level of liability was capped at less than the highest level which the carrier would offer if unconstrained, then the carrier would be precluded from offering the high price/high liability contract which extracts all of the high value shipper's rent and is accepted only by the high value shipper. With this contract no longer possible, the carrier's second best contractual strategy may call for offering two contracts, one which is acceptable to the low value shipper, and one which is acceptable to and yields positive rents for the high value shipper. Both shipper types could thus be better off if a liability limit were adopted instead of the default rule of unlimited liability. However, the carrier clearly must be better off when offering a single, high price contract under unlimited liability (since it was unconstrained, under unlimited liability, from offering the two contract menu but chose the other instead). The carrier therefore will not agree to limited liability.

By precisely the same argument, neither shipper type would accept a movement from limited liability to unlimited liability (the high value shipper would in particular be opposed to such a move, since she earns positive rents under the limited liability default but zero rents under the unlimited liability regime). The carrier would prefer such a move, but it will not be reached by private bargaining.

Thus, in this case (which it should be stressed depends on our assumption that the carrier prefers not to deal with low value shippers when it has unrestricted contractual choice), there may be an argument for limited liability, but it is not the standard Coasean one. Rather, limited liability induces efficient contracting, but it will not be privately agreed upon precisely because it restricts the carrier's ability to offer a contractual menu which induces information revelation. In this example, limited liability should be a mandatory term, imposed on private bargainers to reduce the carrier's ability to discriminate 
among shipper types. This contrasts sharply with the Ayres and GertnerBebchuck and Shavell theory, in which limited liability is the suppletory default term, which is designed to force high value shippers to reveal their value.

\section{The Plausibility of Expansive Default Rules: The Theory} APPLIED

The previous Part of this Article developed a number of theoretical scenarios in which bargaining incentives tend to favor an expansive default rule. This Part exposes my theoretical argument for expansive default rule to the fire of (admittedly) anecdotal empirical confirmation. First, I defend against the possibility that an insurance company, rather than the carrier, might offer to insure the shipper against consequential losses suffered due to the carrier's breach. Next, I argue that the anecdotal empirical evidence regarding bargaining around the rule of Hadley as it is now applied-a rule which in fact is an expansive default damage rule - tends to indicate that bargaining does occur, as my model predicts. One further implication of my model is that this bargaining does not show that the Hadley rule is inefficient. Finally, I argue that my account provides an explanation and a justification for expansive default rules which make contract doctrine consistent overall. My theoretical approach to the Hadley rule explains how the foreseeability limitation on consequential damages is consistent with the limited general duty to disclose prior to contracting set forth in Laidlaw v. Organ, ${ }^{52}$ and consistent also with the hesitancy of courts to enforce liquidated damage provisions. The information-forcing explanation of Hadley given by Posner, Ayres and Gertner, and Bebchuck and Shavell, however, is difficult to square with these other contract doctrines.

\section{A. Adding the (Missing) Market: The Effect of Separate Insurance Against Breach}

It is often possible to obtain insurance against breach from someone other than the promisor. For example, as illustrated by a recent case, it may be possible for a shipper of household goods to agree to limit carrier liability, and then purchase separately, say from Lloyd's of London, an insurance policy for additional coverage against loss due to carrier nondelivery or misdelivery. ${ }^{53}$ If such insurance is available at competitive prices, then it might seem that the information revelation problem I have discussed would largely disappear. Such an insurance market could eliminate both of the informational asymmetries which create incentives for strategic bargaining between the carrier and shipper.

52. 15 U.S. (2 Wheat.) 178 (1817).

53. See Underwriters at Lloyds of London v. North Am. Van Lines, 890 F.2d 1112 (10th Cir. 1989) (holding that under Carmack Amendment to Interstate Commerce Act liability limitation protected carrier against suit by insurer as subrogee of insured's property). 
Insurers might well collect quite accurate information on a particular carrier's breach probability, so that this would no longer be private information known only to the carrier. Competitive insurers would then price policies based on this knowledge of actual carrier breach probability, and the amount of coverage offered. A shipper's actual consequential loss would not affect price in any strategic sense, yet the presence of insurers as monitors of carrier breach probabilities would provide an incentive, through the dependency of the shipper's insurance premium amount on the identity of the carrier selected, for carriers to take precautions to lower the breach probability.

But this is really just to say that the presence of an insurance market where there is full information and where competitively priced insurance against breach is sold makes the default damage rule supplied by contract law largely irrelevant. Indeed, as a general matter, if promisees could costlessly access such a market, then all economic analysis of contract remedies is essentially irrelevant. $^{54}$ The default rule on damages becomes relevant, however, if we assume that the shipper must incur a cost to become aware of and access the market in insurance against breach. But if it is costly to buy third-party insurance (insurance offered by someone other than the promisor) against breach, then it is reasonable to suppose that only those shippers with a lot at stake will seek third-party insurance, since the efficiency gain in getting third-party insurance should in general be larger, the larger the coverage amount sought.

The preference of high value shippers for third-party insurance, however, implies that there is no reason whatsoever to expect shippers and carriers to bargain around a limited liability default rule. Shippers who might want to do so would be better off purchasing third-party coverage against breach loss, even though there is perhaps a larger transaction cost incurred in getting third party coverage, since such coverage is not affected (by hypothesis) by the strategic disadvantages of carrier-offered insurance. Consider, by way of contrast, the story under the expansive default. As I argued in Part II, it is likely that shippers and carriers will bargain around such a default. They bargain to a low liability alternative. Thus, the expansive default gives high value shippers close to what they want, and creates incentives for low value shippers to bargain for what they want, with neither shipper type needing to incur the additional transaction costs in seeking third party coverage. The availability of competitive third-party insurance constrains this kind of bargaining also, and in a socially desirable way-by constraining the carrier's price rather than precluding it.

54. This is not a novel point. If parties could contract, through insurance or otherwise, against every contingency, then contract damage remedies would be largely irrelevant. See Shavell, Damage Measures for Breach of Contract, 11 BELI J. ECON. 466, 468 (1980). 


\section{B. The Empiricist Claim: What Do We Learn From Federal Express?}

As I said in the Introduction, Coasean Contractual Theory is a mixture of theoretical speculation about what would be efficient for most parties, and empirical inference regarding what most parties do. The fact that most parties include a particular sort of contract term is, on this view, strong evidence that the term is efficient. Conversely, the fact that most parties bargain around a particular term is strong evidence that it is inefficient.

In a recent article, Richard Epstein has mounted precisely this sort of empirical attack on the relatively expansive foreseeability default rule on consequential damages. ${ }^{55} \mathrm{He}$ argues that the foreseeability default is inefficient because it conflicts "with the observed limitations in express contractual provisions that can be found today."56 Epstein observes that ordinary sales contracts and the Federal Express shipping contract restrict liability to a level well below the foreseeability default limit. ${ }^{57}$ But of course the liability limitations we observe are written against the background of the foreseeability default rule, and by the very nature of a default rule, we should never observe anything but limitations differing from the default. Thus, even disregarding the information revelation problem entirely, and adopting the simple prescription to choose as the default that term which "most" parties want, the mere existence of deviations from the default does not show that it is not efficient. This conclusion could only be justified by looking also for cases where parties have not altered the default, and finding that these cases are clearly outnumbered by those where they have.

Even a cursory survey, however, reveals many reported cases in which carriers, for example, failed to limit liability as does Federal Express. ${ }^{58}$ These cases do not constitute an unbiased survey of the universe of total cases, ${ }^{59}$ but

55. Epstein, supra note 10 , at 105.

56. Id. at 125 .

57. Id. at 114-22.

58. See, e.g., Starmakers Publishing Corp. v. Acme Fast Freight, Inc., 615 F. Supp. 787, 791 (S.D.N.Y. 1985) (in action under Carmack Amendment to Interstate Commerce Act for damages as result of late interstate delivery of goods, Hadley default limitation applied, with the court noting how Hadley has been "rigorously applied ... . in Carmack Amendment actions"); Affiliated Foods, Inc. v. Puerto Rico Marine Management, Inc., 645 F. Supp. 838 (D.P.R. 1986) (applying Hadley limitation in action for incidental loss under Carriage of Goods by Sea Act, 42 U.S.C. \$ 1300 (1982) (COGSA)); Hector Martinez \& Co. v. Southern Pacific Transp. Co., 606 F.2d 106, 110 (5th Cir. 1979), cert denied 446 U.S. 982 (1980) (in COGSA actions Hadley limitation "does not require the plaintiff to show that the actual harm suffered was the most foreseeable of possible harms. He need only demonstrate that his harm was not so remote as to make it unforeseeable to a reasonable man at the time of contracting.").

59. The fact that these cases went as far in the litigation process as they did may indeed be strong indication that they involved an uncertain area of the law and issues which could not be resolved by settlement, and are in a sense atypical. See Johnston, Uncertainty, Chaos and the Torts Process: An Economic Analysis of Legal Form 76 CORNELL L. REV. (forthcoming 1990) (constructing a theory of ocillatory legal change which relies in part on the selection hypothesis); Priest \& Klein, The Selection of Disputes for Litigation, 13 J. LEGAL STUD. 1 (1984) (setting out and testing this hypothesis). Moreover, I am aware that the existence of even hundreds of cases in which the parties did not bargain around Hadley does not prove that Hadley is efficient for most parties; my point, elaborated in the text below, is merely 
they do resemble Hadley, and occur with sufficient frequency as to cast some doubt on the validity of Epstein's empirical claim that the foreseeability limitation is not the rule which most parties in Hadley-like situations want.

Another feature of the case law which is inconsistent with Professor Epstein's claim is the almost complete absence of reported decisions in which the promisee claimed she told the promisor that she would suffer especially high consequential damages. ${ }^{60}$ Under a restrictive, limited liability default, the promisee must at the very least tell the promisor about such special damages in order to hold the promisor liable for them. To recover such damages under this default rule, the promisee must assert to the court that she made this communication. It is unusual to find cases in which promisees say (truthfully or not) that they told promisors about their otherwise unforeseeable consequential damages. Put more simply, what the theory advanced by Posner, Ayres and Gertner, and Bebchuck and Shavell says should happen does not seem to occur: there simply do not seem to be any cases where the default rule forced the promisee to reveal information about its consequential loss.

One might question the significance of this finding, however, since the Hadley rule we actually have is an expansive foreseeability limitation and not the theoretical avoidability limitation which Hadley itself represents in the law and economics literature. And an expansive foreseeability default creates an incentive to bargain down, for further limits on the promisor's liability for consequential damages; there is no need to bargain up from such a rule. Thus the default rule as actually applied may not be the kind of rule which really tests the information-forcing paradigm.

Still, there are a large number of cases, particularly in the construction area, where parties explicitly include a liquidated damage clause for nonperformance or late performance. ${ }^{61}$ These cases represent instances where the parties have

to show the difficulty in any empirical inference regarding what most parties want.

60. For one of the very rare cases of this sort, see Affiliated Foods, 645 F. Supp. at 844, where the plaintiff said that he told the defendant precisely what the consequences would be of failed delivery. But

' in this case, the defendant allegedly replied by saying that he could not guarantee delivery at a particular time or place, and the court viewed this as an "express rejection of certain special circumstances by one of the contracting parties .... [W] hat we have before us is a party asking the other during the negotiation of the contract to do something and the other answering that it could not promise such a thing." Id.

61. Contracts involving large construction projects routinely contain a clause which stipulates a per diem deduction for delay in completing the job, and such clauses are typically enforced, even over the owner's objection that the stipulated amount turned out to be lower than the owner's actual consequential damages for delay. See, e.g., X.L.O. Concrete Corp. v. John T. Brady \& Co., 104 A.D.2d 181, 482 N.Y.S.2d 476 (1984) (\$2,000 per day deduction for lateness in completing New York University Law School dormitory project enforced over NYU's objection that amount too low). See generally Fortune Bridge Co. v. Department of Transp., 242 Ga. 531, 250 S.E.2d 401 (1978); Murray First Thrift \& Loan Co. v. N.C Paving, 576 P.2d 455 (Wyo. 1978). Also, residential real estate contracts often contain a clause which protects the seller from having to finance two residences by setting a particular fee per day for failure to close the transaction by a certain date. See, e.g., Angell v. Rowlands, $85 \mathrm{Cal}$. App. 3d 536, $149 \mathrm{Cal}$. Rptr. 574 (1978). And in the same context, it is common to find that the vendor's damages in the event of purchaser default are limited to the purchaser's down payment. See Shulkin v. Dealy, 132 Misc. 2d 371, 504 N.Y.S.2d 342 (Sup. Ct. 1986). But cf. Vines v. Orchard Hills, Inc., 435 A.2d 1022 (Conn. 1980) (allowing purchaser to recover some of the down payment on an unjust enrichment theory if the purchaser 
bargained around the uncertain foreseeability limitation, and the related limitation that speculative damages cannot be recovered. ${ }^{62}$ Most of these clauses seem intended primarily to eliminate the need for costly and uncertain litigation to establish actual consequential loss, to replace an uncertain prospect by a certain sum. ${ }^{63}$ With risk aversion, the certain sum will be less than the maximum foreseeable consequential loss which a court might determine and thus such clauses generally confirm my prediction that bargaining will occur around an expansive default. And they also suggest an additional virtue of the expansive default which I have not yet addressed. An expansive default generally increases the variance and hence the uncertainty in the damage award.$^{64}$ If the parties are risk averse, then they will generally benefit more from a certain, liquidated damage agreement, and thereby avoid greater uncertainty. Thus by increasing uncertainty, the expansive default acts as a "penalty" default for the risk averse, and forces them to bargain to lower the probability of litigation. ${ }^{65}$

\section{Doctrinal Consistency}

As a matter of simple or naive positivism, my theory, which says that expansive default rules should be preferred because it is easier for parties to bargain around them, better "explains" existing doctrine, because existing doctrine almost invariably contains an expansive foreseeability default limitation on the recovery of consequential damages but allows parties to limit liability below the default level.$^{66}$ In my view, however, in itself this simple correspondence says nothing much about the theoretical competition I have tried to stage: it may well be that existing doctrine is inefficient.

can show that breach caused the vendor no damages or damages substantially less than the amount of the down payment; otherwise, down payment not exceeding $10 \%$ of the purchase price is a presumptively reasonable liquidated damage amount).

62. As noted in E. FARNSWORTHS, supra note $15, \S 12.15$, at $886 \mathrm{n} .29$ (1982), courts have shown an increasing tendency to weaken the rule forbidding recovery of uncertain or speculative prospective profits. This parallels the increasingly broad interpretation of the Hadley foreseeability limitation which Professor Epstein has criticized.

63. For a similar explanation for why parties include liquidated damage clauses, and a criticism, based on this explanation, of liquidated damage doctrine, see Schwartz, supra note 44.

64. For a nontechnical discussion of how increased variance relates to increased risk, see H. VARIAN, INTERMEDIATE MICROECONOMICS ch. 13 (1987).

65. Litigation cannot be completely avoided, however, because even though such a clause might be mutually beneficial at the time of contracting, it would almost always be true that one of the parties dislikes the clause when it is actually applied and would like to renegotiate it or challenge it in court, because the amount stipulated will almost always fail to equal actual consequential damage.

66. While this is the dominant pattern in the commercial context, courts often refuse to enforce limitations when it is the consumer who has agreed to the limitation. This is true for a variety of contracts. See, e.g., Jones, Private Revision of Public Standards: Exculpatory Agreements in Leases, 63 N.Y.U. L. REV. 717 (1988). For contracts involving the sale of goods, U.C.C. \$ 2-715 (2) adopts the Hadley foreseeability limitation on recovery of consequential damages, and U.C.C. \& 2-719 (3) states that "[c]onsequential damages may be limited or excluded unless the limitation or exclusion is unconscionable. Limitation of consequential damages for injury to the person in the case of consumer goods is prima facie unconscionable but limitation of damages where the loss is commercial is not"; see also J. WHITE \& R. SUMMERS, UNIFORM COMMERCIAL CODE $\S 10-4$, at 386-397, $\S 12-11$, at 471-481 (1980). 
Still, as a doctrinal explanation, my theory has another virtue which the information-forcing theory fails to possess, a virtue which does tend to support my theory's superiority. This is the ability to provide a harmonizing theory, a theory which makes different contract doctrines consistent with one another. If, as Posner seems (at least at times) to maintain, common law contract doctrine is efficient, then it should be that the information-forcing theory, which explains why the avoidability default rule is efficient, accounts equally well for related doctrines.

In this Section, I argue that it does not. The information-forcing theory says that it is efficient to force promisees to reveal information about the magnitude of their consequential loss. But such loss is, in the paradigm case, lost profit, and other contract doctrines, exemplified most famously perhaps by Laidlaw v. Organ, ${ }^{67}$ say that the promisee has no duty to disclose the amount she would lose if the promisor breaches. Moreover, the information-forcing theory implies that contract law should willingly enforce liquidated damage provisions, because it is often only through such a provision that the promisee would be able to increase the carrier's liability, which is the point of revealing information about consequential loss. However, contract law has traditionally been exceptionally suspicious of liquidated damage provisions, presuming, in close cases, that such clauses are as penalties and thus unenforceable. Finally, the information-forcing theory is at odds with the historical background to Hadley. As I will explain, my approach raises none of these problems.

\section{Disclosure Obligations}

In Laidlaw v. Organ, ${ }^{68}$ Organ purchased 111 hogshead of tobacco from Laidlaw \& $\mathrm{Co}^{69}$ Organ made the contract with private information that the War of 1812 had just been ended by treaty, information which eventually caused the price of tobacco to soar above the contract price. When asked by the Laidlaw agent "if there was any news which was calculated to enhance the price or value of the article about to be purchased," Organ apparently was silent. After first transferring the tobacco to Organ, Laidlaw repossessed it, and Organ sued for damages and to prevent Laidlaw from otherwise disposing of the tobacco.

On appeal, the Supreme Court decided that the trial court had incorrectly directed a verdict finding that Organ had not committed fraud, and remanded this issue back for consideration by the jury. But in dicta which both Judge

67. 15 U.S. (2 Wheat.) 178 (1817).

68. Id.

69. My summary of Laidlaw is drawn directly from Maser, Coleman \& Heckathorn, A Bargaining Theory Approach to Default Provisions and Disclosure Rules in Contract Law, 12 HARV. J.L. \& PUB. POL'Y 1801, 1854-55 (1989). 
Posner and Professor Anthony Kronman ${ }^{70}$ take as the Laidlaw principle, Chief Justice Marshall stated that Organ had no obligation to disclose information which was "exclusively within [his] knowledge," since "[i]t would be difficult to circumscribe the contrary doctrine within proper limits, where the means of intelligence are equally accessible to both parties."71

Broadly interpreted, such a principle would clearly conflict with the Hadley principle that a party must disclose the magnitude of her potential loss because she is best informed regarding it. To avoid the conflict, Posner therefore states that the Hadley foreseeability limitation is not applied "where what is unforeseeable is the other party's lost profit," for the reason that "[a]ny other rule would make it difficult for a good bargainer to collect damages unless before the contract was signed he had made disclosures that would reduce the advantage of being a good bargainer - disclosures that would prevent the buyer from appropriating the gains from his efforts to identify a resource that would be undervalued in its present use."72

Judge Posner's resolution of the tension between the Hadley avoidability principle and Laidlaw is ingenious, but unpersuasive. He recognizes that forcing the revelation of information in the Laidlaw case would reduce the advantage of being a good bargainer and cut the return to discovering undervalued resources. But this is exactly what can occur in the Hadley situation as well. There are differences, which the law recognizes, between lost profits as consequential damages and lost profits on the deal, and we could distinguish between Hadley and Laidlaw on this basis. ${ }^{73}$ We might, moreover, emphasize Marshall's dictum in Laidlaw that nondisclosure is permitted $d^{74}$ if the matter which might have been disclosed was "equally accessible" to both parties. That is, the Laidlaw principle might be said to apply only where the information is essentially public and could be discovered by either side, so-that non-disclosure rewards the better information discoverer. ${ }^{75}$ And in Hadley, the information might be viewed as essentially private and unavailable to the promisor.

But this public-private distinction is easy to deconstruct. Information that a war has ended will eventually become public, but when such information was traded on in Laidlaw it was still private, and there is nothing to indicate that the promisor there could have found out about the treaty as quickly as did the

70. Kronman, Mistake, Disclosure, Information and the Law of Contracts, 7 J. LEGAL STUD. 1, 9-18 (1978).

71. 15 U.S. (2 Wheat.) at 195. For a somewhat different economic interpretation of Laidlaw, which focuses on the actual result in the case, see R. COOTER \& T. ULEN, supra note 25, at 259-60.

72. R. POSNER, supra note 22 , at 115 .

73. On the distinction between consequential damages and general difference-in-value damages, see J. WHITE \& R. SUMMERS, supra note $66, \S 10-4$, at 386-87.

74. In fact, what Laidlaw is more conventionally understood to mean is that non-disclosure or silence is, under certain circumstances, not fraudulent.

75. For such an explanation of Laidlaw and related cases, see K.L. SCHEPPELE, LEGAL SECRETS: EQUALITY AND EFFICIENCY IN THE COMMON LAW (1988). 
promisee. ${ }^{76}$ Moreover, how does one decide what it means for information to be "equally accessible" to both sides? If this means that the cost and expected reward to either side from discovering the information is identical, then it must almost always fail to hold.

Even more importantly, it is unclear why the law should reward efforts to discover information about future market price movements with a nondisclosure rule, but adopt a disclosure rule that penalizes promisees who have discovered especially profitable new business opportunities. For example, in a case discussed by Professor Epstein, ${ }^{77}$ performance of a shipping contract would have allowed the shipper to construct a new sawmill in the Pacific Northwest, which as the first mill in that location could have generated very high profits. ${ }^{78} \mathrm{~A}$ severe avoidability default rule on the recovery of consequential damages would have forced the shipper either to disclose that she had discovered such an opportunity or else to accept great contractual risk. But it would seem that this shipper made a much greater and more socially productive investment than did the trader in Laidlaw, so it seems odd that the trader can remain silent while the shipper is forced to disclose. Thus, neither the public-private distinction nor the principle of equal access to information can harmonize Hadley and Laidlaw with the principle of economic efficiency.

My theory, by contrast, admits that the avoidability principle and the Laidlaw nondisclosure rule conflict. The theory defends the strategic robustness of the rule in Hadley as it has actually been interpreted-as an expansive foreseeability default rather than a limited avoidability default. Because this expansive default rule does not force high value shippers to reveal their value, it acts like a nondisclosure rule for such shippers, and it is therefore consistent with Laidlaw.

\section{Liquidated Damage Rules}

According to the information-forcing theory, a limited default rule should force high value promisees to reveal the fact that they will suffer large losses if the promisor breaches, and they should then bargain for a higher price. In other words, this theory says that high value promisees should bargain for liquidated damage clauses. Note that the amounts in such clauses should generally exceed reasonably foreseeable consequential loss, since the default foreseeability rule already provides coverage up to this amount.

The trouble with this story is that liquidated damages doctrine makes it very difficult to bargain for liability that exceeds what is reasonably foreseeable at

76. Scheppele in fact defends the lower court's decision in Laidlaw on the ground that the promisor did not have equal access to the information.

77. Epstein, supra note 10, at 135.

78. British Columbia Saw-Mills v. Nettleship, 3 C.P. 499 (1868). 
the time of breach. ${ }^{79}$ It is not impossible to do so, of course, as the cases that I cited earlier indicate. ${ }^{80}$ Yet in close cases the law says that a liquidated damage amount that looks too high should be deemed unenforceable as a penalty. ${ }^{81}$ This attitude is hard to square with the avoidability principle represented by Hadley, since it tends to make it very difficult for bargainers to do precisely what the avoidability principle tells them to do.

By contrast, my theory of strategic incentives explains the law's rather skeptical attitude toward liquidated damage clauses. ${ }^{82}$ Under an expansive default, high value promisees are already fully covered against loss from breach. A promisor could actually pay a bonus to a high value promisee in exchange for information about the size of the promisee's loss, and both would be better off given that the promisor's ability to take the correct level of precautions in light of the actual loss to be prevented lower her expected total cost from the contract. The social problem is to give such a promisee an incentive to reveal her value from the contract, while at the same time ensuring that a low value type does not pretend to be a high value type just to get what would in effect be a liquidated damage bonus above and beyond her actual loss. One way to solve this problem is to monitor, ex post, the correspondence between the promisee's actual damages and the liquidated damage amount, and to refuse to enforce disproportionately large liquidated damages. With sufficiently accurate monitoring, liquidated damage clauses become an informationally feasible method for a promisee to communicate that her consequential damages will be unusually high. I argued earlier that low value promisees will generally have an incentive to bargain for less coverage than provided by an expansive default. On my view, liquidated damage doctrine may also make it possible for high value promisees to reveal their values, so that there is no strategic impediment in either direction to bargaining around the expansive default rule.

79. The courts have evolved a balancing test that makes the enforceability of liquidated damages provisions depend primarily upon (a) whether the stipulated damage amount seems in the light of hindsight to have been a reasonable ex ante forecast of foreseeable consequential loss, and (b) whether the actual damages from breach are difficult to measure, and hence to recover, without a liquidated damage provision. On this test, see generally Wassenaar v. Panos, 111 Wis. 2d 518, 529-31, 331 N.W.2d 357, 362-63 (1983); Macneil, Power of Contract and Agreed Remedies, 47 CoRNell L.Q. 495, $507-08$ (1962).

80. See cases cited supra note 58.

81. See, e.g., Vernitron Corp. v. CF 48 Assocs., 104 A.D.2d 409, 478 N.Y.S.2d 933, 934 (App. Div. 1984); National Telecanvass Assoc. v. Smith, 98 A.D.2d 796, 470 N.Y.S.2d 22 (App. Div. 1980); Mayor of Brunswick v. Aetna Indem. Co., 4 Ga. App. 722, 728, 62 S.E. 475, 478 (1908).

82. For other economic approaches to the liquidated damages problem, which do not make the point I raise here, see Clarkson, Miller \& Muris, Liquidated Damages vs. Penalties: Sense or Nonsense?, 1978 WIS. L. REV. 351 (1978); Goetz \& Scott, Liquidated Damages, Penalties and the Just Compensation Principle: Some Notes on an Enforcement Model and a Theory of Efficient Breach, 77 COLUM. L. REV. 554 (1977); Note, Liquidated Damages and Penalties under the Uniform Commercial Code and the Common Law: An Economic Analysis of Contract Damages, 72 Nw. U.L. REV. 1055 (1978). For a summary of economic arguments in favor of routine judicial enforcement of liquidated damages, see $R$. COOTER \& $T$. ULEN, supra note 25, at 293-95. 


\section{Hadley's Historical Background}

A final note goes to the relationship between the theoretical and historical understanding of Hadley. Other things equal, it would seem that a theoretical explanation ought to be consistent with the historical understanding of a doctrine as important as the rule in Hadley. According to Richard Danzig's pathbreaking historical account, ${ }^{83}$ one of the things that the court sought to accomplish in Hadley was to give carriers some kind of liability limitation, in the face of impending parliamentary action that would have had the effect of precluding carriers from effecting their own limitation through private contract. ${ }^{84} \mathrm{My}$ theoretical account explicitly depends upon judicial enforcement of express contractual liability limitations. If these are not enforced, then an expansive default rule will lead carriers to charge very high prices under unlimited liability, prices which lead to a much lower probability of contracting than is socially optimal. ${ }^{85}$ Under these conditions, the limited liability default rule - the actual result in Hadley - may be superior on efficiency grounds, even if nobody bargains around the default, because it induces carriers to set a lower price and comes closer to the socially optimal.

\section{CONCLUSION}

I began this Article by expressing a belief, a belief in economics as a source of insight into the law. As applied to the problem of crafting contract default rules, I have tried to show that recent economic insights into bargaining and strategic information transmission generally suggest that it will be easier for parties to bargain around expansive default rules than around restrictive or penalty default rules. If this is so, then the law's preference for expansive default rules may be efficient. I say "may be" because it is possible that if transaction costs are very high, and most parties want what they in fact get under a penalty default, then bargaining around an expansive default involves what is essentially needless transaction cost.

But my primary object here has not been to defend the efficiency of expansive default rules. Rather, my main goal has been to show that the established information-forcing theory of default rules fails to account adequately for strategic incentives in bargaining around the default-to point to some serious cracks in the theoretical foundation underlying a central case in contract law. For if we too blithely take the foundation as solid, then what may in fact be

83. Danzig, Hadley v. Baxendale: A Study in the Industrialization of the Law, 4 J. LEGAL STUD. 249 (1975).

84. Id. at 265-66.

85. For a similar, more general argument that expectation damages may be inefficient when imposed in a market where the seller has market power and already sets too high a price, see Friedman, An Economic Analysis of Alternative Damage Rules for Breach of Contract, 32 J.L. \& ECON. 281 (1989). 
an economic-legal principle of rather limited and special validity becomes a general truth of the common law, another confirmation of the common law's close correspondence to principles of economic efficiency. Indeed, it is probably possible to find some economic explanation for every important common law doctrine, and then to construct and extend the common law based on the set of received economic explanations. ${ }^{86}$ Yet economic efficiency has many aspects and meanings which depend (among other things) upon the informational environment supposed to exist. ${ }^{87}$ And common law doctrines are overdetermined-they can be explained from a variety of perspectives. ${ }^{88}$ "Explaining" the common law from an economic point of view can therefore mean simply choosing a set of assumptions and notions of efficiency. My goal here (and elsewhere) has been to expose this choice and its consequences, to attempt to demystify the economic analysis of law.

86. I explore these themes in more detail in Johnston, supra note 1, and in a work in progress, J. Johnston, Explaining Cases (unpublished manuscript available at Vanderbilt Law School).

87. See Holmstrom \& Myerson, Efficient and Durable Decision Rules with Incomplete Information, 51 ECONOMETRICA 1799 (1983).

88. See Cooter, Unity in Tort, Contract and Property: The Model of Precaution, 73 CaLIF. L. REV. 1 (1984). 


\section{APPENDIX A}

This Appendix develops a simple model in which a carrier will bargain around an unlimited liability default rule but will not bargain around the limited liability default rule. As in the text, by "limited" liability default rule I mean a rule which caps carrier liability at a level far below the maximum forseeable shipper loss. By "unlimited" liability I mean a rule which makes the carrier liable for all foreseeable shipper consequential losses.

The analysis proceeds on the basis of several assumptions. I assume that the bargaining process is very simple, with the carrier making a single take-itor-leave-it offer to the shipper. ${ }^{1}$ The offer is what I refer to in the text as "single price": the carrier simply quotes a price for a single level of liability, for example, the level provided by the default rule. I assume also that the carrier's level of precautions against breach and hence the probability of breach is fixed. We let $q$ denote this probability of breach (failure to deliver), and assume that this probability is common knowledge. Both the shipper and carrier are assumed to be risk neutral. Let the shipper's value from successful carriage of the good be a random variable, $v$, with uniform distribution on $[0, \hat{0}]$, the actual value of which is observed only by the shipper. Similarly, let $L$ denote the carrier's (random) liability in the event of breach. Note that liability limitations generally cause $L$ to differ from $v$. Finally, to focus solely on rent extraction and creation through the bargained price, assume that the carrier's cost is zero, and that the shipper's reservation profits are zero also. ${ }^{2}$

We solve first for the price under alternative default damage rules. The carrier's problem is simplest under the legal default of unlimited liability, which is favorable to shippers with high damages. In this case, (recalling our assumption that $v$ is uniformly distributed), the carrier's problem becomes:

1. At the conclusion of this Appendix, $I$ explain how the results may be quite robust to variations in my assumptions about the extensive form of the bargaining game. The assumption that the carrier makes a single take-it-or-leave-it offer gives the carrier great bargaining power, but such power may exist in bargaining even if the carrier is not a monopolist in the shipping market. For example, Perry, An Example of Price Formation in Bilateral Situations: A Bargaining Model with Incomplete Information, 54 ECONOMETRICA 313 (1986), has shown that when valuations of the object to be traded are privately known but bargaining costs are matters of common knowledge, the unique sequential equilibrum has the side with the lower cost of waiting making an offer which the other side will either accept or reject by terminating the bargaining-i.e., the unique sequential eqilibrium involves a single take-it-or-leave-it offer. For an application of this result to cheap-talk games (games with messages that are not directly relevant to the payoff), see J. Farrell \& R. Gibbons, Cheap Talk, Neologisms and Bargaining (University of California, Berkeley, Dept. of Economics Working Paper No. 8883). For an application pointing out the general inefficiency of private bargaining under incomplete information but clear property rights, see Samuelson, A Comment on the Coase Theorem, in GAME-THEORETIC MODELS OF BARGAINING 321 (A. Roth ed. 1985).

2. This obviously rules out the kind of efficiency gains through optimal, full-information precautions which motivate the "information-forcing" paradigm. Below, however, I explain why the problem of rent dissipation through information revelation can prevent such gains from being realized. 


$$
\max _{p} \frac{(\hat{v}-p)}{\hat{v}}((p-q)(p+\hat{v}) / 2)
$$

This problem is derived by observing that under full liability for consequential loss, a shipper is assured of getting her actual value $v$ regardless of whether or not the contract is fulfilled, and thus contracts if and only if $v>p$. The carrier's expected damages given that the shipper has accepted at price $p$ are therefore given by $(p+\hat{v}) / 2$.

The first order condition for this problem defines the optimal price under unlimited liability, $P_{u}$ (and also confirms that the second order condition is satisfied) through the equation:

$$
P_{u}=\hat{v} /(2-q)
$$

Note that as typical of many bargaining models with incomplete information, the carrier's price is not ex post efficient-many shippers whose value exceeds the carrier's cost may fail to contract for carriage at price $P_{u}$. The price falls with the probability of breach, but always equals or exceeds the shipper's costs (since $v \leq \hat{v}, \hat{v} /(2-q) \geq q v$, where $q v$ is the shipper's cost of providing full coverage). Thus under unlimited liability, the carrier charges an inefficiently high price which effectively prevents many low and moderate value shippers from trading.

Consider next the situation under a limited liability default rule, which says that carriers are only liable up to a ceiling which if less than the maximum foreseeable loss. One plausible formalization of such a rule is that carrier liability cannot exceed average foreseeable shipper loss. Under this default rule, the carrier's expected liability, given acceptance at price $p$, and probability of acceptance, are nondifferentiable at the point $p=\bar{v}$, where $\bar{v}$ equals the expected value of $v$ (and hence equals $\hat{v} / 2$ under our assumption on the distribution of $v)$. To solve the carrier's pricing problem, let us assume first that $p \geq \bar{v}$. This assumption turns out to be consistent, and we can then check also that there is no consistent solution under the assumption that $p<\hat{v}$.

If $p \geq \bar{v}$ but carrier liability is capped at $\bar{v}$, then a shipper will only accept the contract at price $p$ if $v \geq \bar{v}$, and if:

or if

$$
(1-q) v+q \bar{v}-p>0
$$

$$
v>(p-q \bar{v}) /(1-q) .
$$


Since only those shippers with $v>\bar{v}$ accept at $p>\bar{v}$, carrier liability is fixed at $\bar{v}$, and the carrier's pricing problem becomes:

$$
\max _{p} \frac{\hat{v}-(p-\bar{q}) /(1-q) .}{\hat{v}}
$$

The first order condition for this problem in turn implies that the price with limited liability, $P_{l}$, equals $\bar{v}$. This solution is consistent with the assumption underlying the problem that $p \geq \bar{v}$. To see that assuming the converse does not yield a problem with a consistent solution, note that when $p \leq \bar{v}$ but liability is capped, the carrier's expected return is equal to:

$$
\frac{(\hat{v}-p)}{v}\left[P-q\left[\frac{(\bar{v}-p)}{(\hat{v}-p)} \frac{(p+\bar{v})}{2}+\frac{(\hat{v}-v)}{(\hat{v}-p)}\right] \bar{v}\right]
$$

The partial derivative of (A4) with respect to $p$ evaluated at $p=\bar{v}$ is greater than zero, so that (A4) does not have a consistent solution.

We thus have that under unlimited liability, the carrier's price will be:

$$
P_{u}=\hat{v} /(2-q),
$$

while he will charge $P_{l}=\overline{\mathrm{v}}$ under limited liability.

As I argued in the text, a shipper could bargain around either default rule by simply telling the carrier what her damages are, and asking for coverage in this amount. If the carrier believes such a message, however, then any shipper who would have contracted under the default rule will not send the message. This is because under either default rule, shippers who contract earn positive informational rents-because the carrier does not know the shipper's actual value, he cannot extract all of this value through the price he charges. To see - how the shipper would be harmed by revealing her private information, consider a shipper whose value exceeds $\bar{v}$. This shipper has no incentive to reveal her value under unlimited liability, because she is already fully covered. She also has no incentive to reveal under limited liability, because if her revelation is truthful, the carrier will extract all her value by offering full coverage at a price of $v$, and refusing anything but this contract. The carrier will prefer this, since under limited liability his profit selling to this particular shipper was $\bar{v}-q \bar{v}$ and would be $v-q v$ under the new full information deal. Anticipating such a response, the shipper would be foolish to reveal her actual value. 
There are, of course, other ways for a shipper to communicate her dissatisfaction with the status quo liability rule than by flatly revealing her full value from the contract. One plausible alternative is for the shipper to ask for a higher liability limit, to request some limit $L$, with $L>\bar{v}$. In general, $L$ may be above or below $v$, the shipper's actual value (loss), and so merely requesting $L$ does not fully reveal the shipper's value. However, as will now be shown, if the default is limited liability, then there is no mutually agreeable increase in liability when the carrier is aware of the information revealed by a shipper's acceptance of such a deviation. Moreover, with information revelation, there is no mutually agreeable liquidated liability amount (i.e., payable regardless of actual loss) above $v$.

To see this, assume that a shipper with value $v>\bar{v}$ proposes liquidated damages in the amount $L$. If the price for this liquidated damage clause is $p(L)$, the shipper will opt for this package over the limited liability default if and only if:

$$
(1-q) v+q L-p(L)>(1-q)(v-\bar{v})
$$

or if

$$
p(L)<q L+(1-q) \bar{v}
$$

But then any liquidated damage clause which is accepted in lieu of the limited liability default yields profits for the carrier less than:

$$
(q L+(1-q) \bar{v})-q L=(1-q) \bar{v}
$$

so that profits are lower than under the default. Hence liquidated damages above $\vec{v}$ should not be observed.

We can now interpret $L$ as a liability cap exceeding the liability default value, rather than as liquidated damages. Observe first that for any shipper with $v>L, L$ still acts as a liquidated damage clause, and is accepted only under condition (A5), and hence will not be agreed to by the carrier.

Any shipper with $v<L$ is fully insured under the contract $(p(L), L)$, and prefers this to the default deal only if:

$$
p(L)<q v+(1-q) \bar{v}
$$

But any price which satisfies (A6) lowers the carrier's profits from selling to any type $v<L$ who accepts (as follows immediately from (A6)). Acceptance at price $p(L)$ reveals that the shipper's actual value $v$ is such that the price increase is less than the carrier's increase in expected liability. Thus any liability limit $L$ exceeding $v$ which is priced so that it would be strictly pre- 
ferred to $v$ by some shipper type must reduce carrier's profit from contracting with that shipper type. Since increases in liability cannot reduce the carrier's price, they do not increase the probability of agreement, but only lower the carrier's profit given agreement. Thus because the carrier realizes that any shipper who accepts a high liability contract does so only because the price increase is more than offset by the coverage increase, he realizes that any acceptance has lowered his profit. What is good for a shipper is bad for the carrier.

Incentives differ dramatically with proposals to contract downward from unlimited liability. Recall that the price under unlimited liability equals $\hat{v} /(2-q)$, so that as $q$ increases from zero, the price increases towards $\hat{v}$, and fewer and fewer shippers accept the contract under the default rule of unlimited liability. Recall also that the price for limited liability was $\bar{v}$, which is invariant with respect to $q$. If a shipper proposes a deviation from unlimited to limited liability, the carrier may still lose profits if the shipper accepts the price charged for lower liability, because the shipper's damages may be such that for her the decrease in price more than offsets the reduction in coverage, but it also may be that the shipper's value is so low that she would not have accepted the limited liability contract. For example, if the probability of breach, $q$, equals $1 / 2$, and the limited liability contract offers coverage up to $\bar{v}$ at price $\bar{v}$, then by making the limited liability contract available when it is requested, the carrier loses profits on shippers with values between $(4 / 6) \hat{v}$ and $(5 / 6) \hat{v}$, who effectively masquerade as types who would not have purchased and opt for the lower liability package, but the carrier gains the business of shippers with values between $(3 / 6) \hat{v}$ and $(4 / 6) \hat{v}$, who really would not have purchased the full liability contract. (Shippers whose value exceeds $(5 / 6) \hat{v}$ still purchase the full liability contract). And as can be easily confirmed, carrier profits increase by a non-negligible amount ${ }^{4}$ when the request for lower liability is met. ${ }^{5}$

Because I've utilized a very simple and quite special bargaining model in this Appendix, a few remarks on how the results might change in a more general model are in order. The shipper-carrier bargaining problem where the carrier's breach probability is common knowledge but the shipper's value from the contract is known only to the shipper is, generically, a bargaining problem with one-sided private information which is correlated with the other side's

3. More generally, for an arbitrary default limitation $L$ the price will equal $\not(1-q) / 2+q L$.

4. The increase is equal to $[(1 / 16)-(1 / 36)]$.

5. Similar results can be obtained for limited liability options with even lower liability limits. If, for example, $L=1 / 4$ and $q=1 / 2$, then shippers with $v$ such that $1 / 2<v<5 / 6$ opt for limited liability and those with $v>5 / 6$ opt for unlimited. By offering both contracts, the carrier's profit is $17 / 144$, whereas profit is only $12 / 144$ with just the unlimited contract. 
value. In this problem we might imagine that what the carrier would like to do is to make a sequence of descending offers, as he tries to get as much as possible from the shipper. The shipper's value is also the carrier's damage payment in the event of breach, and thus the carrier must be concerned that while a low price increases the probability of quick agreement, it also might be accepted by a high value (high damage) shipper who holds the carrier to an unprofitable contract. By first offering only a very high price, and then decreasing price slowly, the carrier might try to solve this problem by forcing the high value shipper to agree early at a relatively high price rather than incur what might be substantial costs due to delayed agreement.

Recent work, ${ }^{6}$ however, has shown that the carrier may be unable to do this strategy. If the shipper is patient enough (has low enough delay costs) then the sequence of descending offers may inevitably involve a net loss to the carrier, as high value shippers simply wait. The carrier may make a single high price take-it-or-leave-it offer. Thus while my simple model of carrier-shipper bargaining is clearly not the best mechanism for maximizing joint surplus from the contract, it may emerge as an equilibrium behavior even when more complicated strategies involving a (possibly infinite) sequence of offers and counteroffers are possible.

6. See Evans, Sequential Bargaining with Correlated Values, 56 REV. ECON. STUD. 499 (1989); D. . Vincent, Bargaining with Common Values (CMSEMS Discussion Paper No. 775, 1988, available at Northwestern University). 


\section{APPENDIX B}

This Appendix explains some of the points made in Part II.B.1 of the main text. That Section argued that when the carrier's breach probability is not perfectly known by the shipper, the carrier faces conflicting strategic incentives in bargaining around a limited liability default. This conflict can be presented in a formal and succinct way using the same notation developed in Appendix A.

Consider a shipper whose value from the contract, $v$, exceeds maximum carrier liability under the limited liability default, which as before is given by $\bar{v}$. Such a carrier earns non-negative returns from the limited liability contract offered at a $P_{l}$ only if we have:

$$
q \bar{v}+(1-q) v-P_{l}>0,
$$

where we now interpret $q$ as the shipper's belief about the carrier's breach probability. This belief may not be correct, and in general will be based both on prior information about the carrier-its reputation, for instance-and specific information conveyed by the carrier. Clearly, the left hand side in inequality (A7) is decreasing in $q$ for any $v>\bar{v}$. If we think of a distribution of possible shipper values $v$, then the probability that the shipper will accept the default contract decreases as $q$ increases, because as $q$ becomes large, only carriers with very high value from successful performance are able to earn non-negative profits from the contract despite the high probability of breach. To get a high probability that the shipper will accept the limited liability default contract, therefore, the carrier needs to persuade the shipper that $q$ is low. Importantly, for any shipper with $v>\bar{v}$, the carrier's limited liability default breach probability affects the shipper's return from the contract, so that the limited liability default necessarily makes private information known only to the carrier relevant to the shipper's decision about whether to contract.

For a shipper to prefer full coverage of all of her consequential losses, at a (higher) price $P_{u}$, it must be that:

$$
q \bar{v}+(1-q) v-P_{l}<v-P_{u}
$$

or more simply,

$$
P_{u}<q(v-\bar{v})+P_{l} .
$$

That is, the shipper must get a higher net return from the full coverage or unlimited liability contract than from the limited liability contract. As a direct consequence, we have from inequality (A8) that the higher is $q$, the breach probability under the default, limited liability situation, the higher the price, $p_{u}$, which the shipper will pay for the full coverage contract. But the higher is $q$, 
the lower is the probability that the shipper will want the default contract, so that in order to charge a high price for the full coverage contract, the carrier must necessarily convey information which lowers the probability of reaching agreement on the limited liability default contract.

Consider now how things change if we begin with the full coverage default rule. With full coverage, the carrier's breach probability is not relevant to the shipper in computing value from the contract. Full coverage, however, induces the carrier to charge a high price, with a low probability of agreement. For this reason, the carrier has an incentive to communicate that his breach probability is low, and to offer, at the same time, a limited liability default contract. This joint communication-proposal may greatly increase the probability that the carrier will contract (and accept the limited liability, low price alternative). 


\section{APPENDIX C}

This Appendix sketches in more detail the signaling argument presented in Part II.C of the text. I say "sketch" because I do not present a formal proof here; this will be done in another, more appropriate context. In the text, I claimed that high quality carriers might naturally signal their type under a limited liability default by charging a high price and that there therefore would be no signaling incentive to bargain around the limited liability default. Conversely, I said that signaling might not occur under an unlimited liability default, which would force low quality carriers to offer limited liability and thereby signal carrier type with both price and liability coverage.

These claims can be established within the following simple, but quite stylized model. Suppose there are two kinds of carrier, good (low breach probability, high care level and hence cost of precautions against breach), and bad (high breach probability, low care level and hence cost of precautions against breach). To simplify, assume that the bad carrier takes no precautions against breach and has therefore zero cost of precautions. Suppose also that there are two default rules on consequential damges, limited and unlimited. Turning now to the shipper's side, assume that there are two kinds of shipper, low value and high value. Assume that shippers and carriers are risk neutral, and assume that the limited liability default rule provides full coverage for low value shippers but leaves high value shippers with uncompensated consequential damages in the event of breach. For simplicity, assume finally that there is one good carrier and one bad carrier, and let us embody these assumptions in the following notation:

$q_{i}=$ carrier breach probability, for $i=g$ (good), and $b$ (bad), with $q_{g}<q_{b}$;

$c=$ cost of precautions against breach taken by the good carrier;

$v, V=$ shipper consequential losses (lost profit) in the event of carrier breach, with $v<V$;

$\theta=$ probability that a shipper has low consequential losses, i.e., $\theta=$ Prob[shipper loss $=v]$.

Consider now equilibrium in this market when the default rule provides for limited liability, which means that carrier liability is capped at the level $v$. Assume that:

$$
q_{g} v+c>q_{b} v,
$$

that is, under limited liability, the bad carrier has lower expected total cost than the good carrier. Assume also, however, that for some price $P(G)>\left[q_{g} v+c\right]$, 


$$
\left(1-q_{g}\right) V+q_{g} v-P(G)>\left(1-q_{b}\right) V+q_{b} v-q_{b} v
$$

so that a good carrier could earn non-negative rents and still charge a price that would attract high value shippers away from the bad carrier, even if the bad carrier set price equal to his cost. Condition (A9) ensures that the bad carrier can charge a price under limited liability which is so low that a good carrier cannot mimick him and stay in business. Condition (A10) ensures that there are prices at which the good carrier can attract some shippers even under limited liability.

We wish to show that there exists a stable separating equilibrium under limited liability: an equilibrium in which carriers perfectly identify their type through the price charged. For a notion of stablility, we use the refinement of sequential equilibrium which Cho and Kreps have called the intuitive criterion. ${ }^{7}$ In the present context, the natural separating equilibrium under limited liability has the good carrier charging a high price and serving the high value shippers and the bad carrier charging a low price and serving the low value shippers. Conditions (A9) and (A10) ensure that many such equilibria would be stable with respect to attempts by the good carrier to obtain the bad carrier's business by lowering price: there exist bad carrier prices which cannot be profitably mimicked by the good carrier. To ensure that such an equilibrium is also stable with respect to attempted deviations by the bad carrier to obtain the good carrier's business, we need only assume that the proportion of low value shippers, $\theta$, is sufficiently high. For then the bad carrier would be worse off if he mimicked the good carrier's high price, because even if he was believed to be a good carrier, the loss from sharing the business of low value shippers would be greater than the gain from the higher price.

Now consider the situation under an unlimited liability default. Suppose that we have:

$$
q_{8} \bar{v}+c<q_{b} \bar{v}
$$

7. I imagine generally an extensive form in which carriers announce prices, shippers update their beliefs on the basis of these prices, and then choose whether and with whom to contract. This is essentially the same kind of extensive form, with appropriate modifications, modeled in the price-quality signaling literature, especially K. Bagwell \& M. Riordan, High and Declining Prices Signal Product Quality (CMSEMS Discussion Paper No. 808 (1988) available at Northwestern University). The sequential equilibrium concept due to Kreps \& Wilson, Sequential Equilibria, 50 EcONOMETRICA 863 (1982), can then be applied to rule out equilibria in such a game which essentially rely on threats ('I won't contract with you unless the price is ..."), which are irrational to carry out when they are called, and applied also to impose the requirement that on the equilibrium path beliefs are updated according to Bayes' Rule (and off the equilibrium path, beliefs are consistent in that they can be derived as the limit of a sequence of beliefs formed according to Bayes' Rule). The intuitive criterion due to Cho \& Kreps, Signaling Games and Stable Equilibria, 102 Q.J. ECON. 179 (1987), then rejects as unstable those pooling equilibria in which, for example, one type of carrier would be better off with a strategy (such as charging a price) different than the equilibrium profile and the other type of carrier would be worse off with such a strategy even if the shipper thought he was the other type (because if such a strategy existed the shipper would be correct in this belief). 
where $\bar{v}=[\theta v+(1-\theta) \mathrm{V}]$. That is, the good carrier's expected total cost from serving both types of shipper under unlimited liability may be less than the bad carrier's expected total cost under unlimited liability, because under unlimited liability, the good carrier's high level of precautions is more efficient. ${ }^{8}$ If condition (A11) holds, and we continue to assume that the proportion of low value carriers is quite high, then the good carrier would be best off-given the default damage rule-charging a high price and mimicking the bad carrier. If he does not do so, then he gives up profits with no corresponding gain in business. ${ }^{9}$ The unlimited liability default leads to a pooling equilibrium which it is to the bad carrier's advantage to break by offering limited liability as an alternative.

8. I have simplified by assuming that carrier precautions are fixed. But the same sort of results would obtain if we worked instead with reduced form expected total cost functions derived from a problem in which carriers minimized expected total cost over the level of precautions, but the good and bad carriers differed, one having low marginal cost but relatively low marginal productivity of precautions, the other having high marginal cost but relatively high productivity of precautions.

9. The only business he could gain would be the business of high value shippers. But to get this business he must charge a low enough price-given unlimited liability-to reveal himself as a good carrier, and as soon as he does this, the low value shippers will depart for the bad carrier. 


\section{APPENDIX D}

This Appendix expands the analysis to consider contracts which are more complex than those considered previously in that they involve price-liability menus. Previous appendices assumed that the carrier simply offered a single price given the liability limit provided by the default rule. However, a carrier could always do at least as well, and generally do better, by offering a menu of contracts, with each contract specifying liquidated liability $L_{i}$ at price $p_{i}$, for shipper of type $i$. Such a menu would be designed to extract as much of the shipper's rent as possible, subject to the two constraints that the shipper agree to contract (that the contract satisfy the shipper's individual rationality constraint by giving her at least her reservation profit or utility) and that the shipper truthfully reveal her value from the contract (that the contract be incentive compatible).

Such a menu is thus designed to discriminate in price among shippers with differing value from the contract. The carrier's ability to effect such discrimination depends upon the presence of some power over price, and to simplify the analysis, this Section will simply assume that the carrier is a monopolist. My object in this Section is to demonstrate that when such a monopolistic carrier can offer a discriminatory menu of carriage contracts, there are circumstances under which neither the limited nor the unlimited liability default will be bargained around. Limited liability may be preferable under these circumstances because it forces the carrier to offer contracts which are acceptable to both low value and high value shippers, which the carrier may not rationally do under unlimited liability if the proportion of high value shippers is sufficiently high. $^{10}$

If shippers have linear willingness to pay for liability coverage, as in the previous part, then there will not be a unique type-contingent menu of contracts. To get better insight into incentives under a type-contingent menu, let us assume that shippers are risk averse, and are identical except for the value they place on successful performance of the carriage contract. Assume further that there are two types of shippers-low and high value-denoted by $v_{1}$ and $v_{h}$. A carriage contract with price $p$ and coverage $L$, yields expected utility for a shipper with value $v_{i}$ of:

$$
q u(L-p)+(1-q) u\left(v_{i}-p\right) .
$$

Shippers are risk averse, so that $u^{\prime}>0$ but $u^{\prime \prime}<0$. Assume for simplicity that the carrier has zero cost and breaches with probability $q$, and is risk neutral.

10. The analysis in this section is similar to, but much less general than the analysis in Besanko, Donnenfeld \& White, Monopoly and Quality Distortion: Effects and Remedies, 102 Q.J. ECON. 743 (1987), who examine a model of monopolistic discriminatory price-quality menus with a continuum of consumer types, and show how minimum quality standards and price ceilings may increase social welfare. 
The carrier thus seeks to maximize expected profit, which for any contract $(L, p)$ equals $p-q L$. If we let $F_{i}$ represent the probability that a shipper has value $v_{i}$, then the carrier's problem is to find a contract which induces the shipper to reveal her type $i$ and maximizes expected carrier profits. When there are no limits on $L$, the carrier's liability, this problem can be written succinctly as:

$$
\begin{array}{ll}
\max & F_{l}\left(p_{l}-q L_{l}\right)+F_{h}\left(P_{h}-q L_{n}\right) \\
\left(L_{i}, p_{i}\right) &
\end{array}
$$

subject to:

$$
q u\left(L_{i}-p_{i}\right)+(1-q) u\left(v_{i}-p_{i}\right) \geq 0, \text { for all } i,
$$

and

$$
q u\left(L_{i}-p_{i}\right)+(1-q) u\left(v_{i}-p_{i}\right) \geq q u\left(L_{j}-p_{j}\right)+(1-q) u\left(v_{i}-p_{j}\right),
$$

for all $i, j \neq i$.

In standard fashion, the constraints (A14) and (A15) can be simplified by observing that (A14) will bind only for the low value shipper (since any contract yielding non-negative utility to the low value type yields non-negative utility to the high value type, but not vice versa), and that (A15) binds for the high value shipper.

Figure 1 depicts a possible solution of special interest. ${ }^{11}$ In the Figure, the only contract offered is depicted by point $A$. This contract maximizes the carrier's profit from selling to just the high value shipper. He therefore needs to satisfy only the constraint that the high value shipper have non-negative profit from the contract, and therefore point $A$ lies on the high value shipper's zero surplus indifference curve labeled $I_{h o}$ in the Figure. Offering only a contract which is accepted by the high value shipper will be optimal strategy for the monopolistic carrier if the proportion of high value shippers is high enough. To see this, note that anytime a contract which is acceptable to the low value shipper is also offered, the carrier must offer the high value shipper a contract which gives the high value shipper positive rents, because the high value shipper is always, by definition, able to get positive rent from the low value shipper's contract. Thus, when the carrier offers two contracts-for example, in Figure 1, contracts $B$ (to the high value shipper) and $C$ (to the low value shipper)-he sacrifices some profits on contracts with high value shippers.

11. The general solution to this sort of screening problem is developed in, for example, J. TTROLE, THE THEORY OF INDUSTRIAL ORGANEATION 142-45 (1988); Cooper, On Allocative Distortions in Problems of Self-Selection, 15 RAND J. ECON. 568 (1984); Maskin \& Riley, Monopoly With Incomplete Information, 15 RAND J. ECON. 171 (1984). 
This sacrifice can only be worthwhile if the proportion of low value shippers is sufficiently high, for otherwise the profits from contracts with low value shippers will not be sufficient to offset the lost profits on contracts with high value shippers. ${ }^{12}$

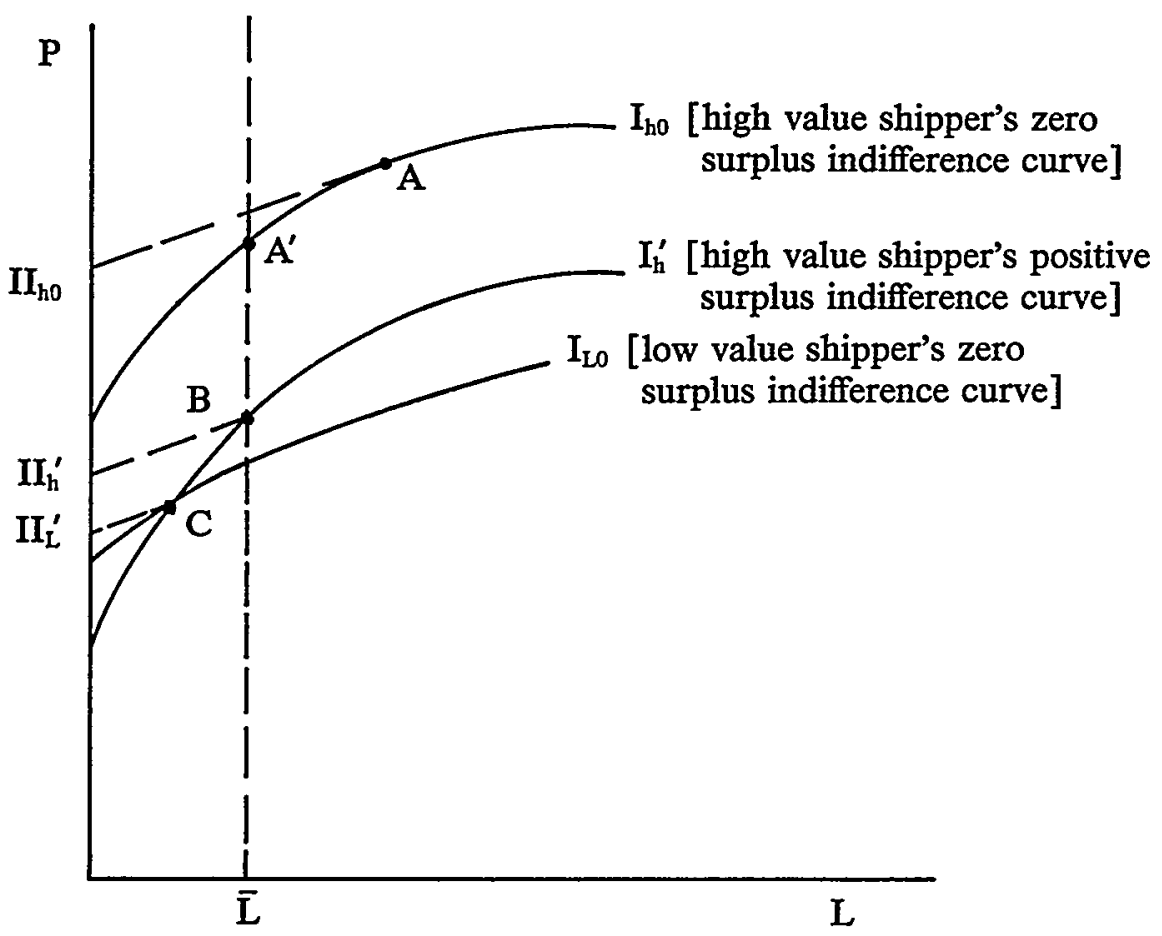

Figure 1

Somewhat more formally, the carrier will earn profits of $F_{h} I I_{h o}$ if it offers only contract $A$ and serves only high value shippers. Carrier profits will be $\left[F_{h} I I_{h}^{\prime}+\left(1-F_{h}\right) I_{L}^{\prime}\right]$ if it offers both contracts $B$ and $C$ and serves both types of shippers. Because $F_{h}$ is high, it may well be that the carrier prefers, given unrestricted choice, the contract $A$. But consider now the effect of imposing a mandatory liability limitation, such as the cap at level $\bar{L}$ depicted in Figure 1.

12. The isoprofit lines depict the equation $p=I I+q L$ for different values of the profit $I I$. The indifference curves have slope $\left.q u^{\prime}(L-p) / q u^{\prime}(L-p)+(1-q) u^{\prime}\left(v_{i}-p\right)\right]>0$, and satisfy the single-crossing or "sorting" condition since $u^{\prime}(0$ decreases in its argument.

For a similiar graphic presentation of this result in a more standard insurance context, see J. TRROLE, supra note 11, at 162. For the general result, see Stiglitz, Monopoly, Nonlinear Pricing and Imperfect Information: The Insurance Market, 44 REV. ECON. STUD. 407 (1977). 
Because $\bar{L}$ is so much lower than the amount of coverage which the carrier would ideally offer only to the high value shipper, contract $A^{\prime}$ brings much lower carrier profits than contract $A$. Clearly if this decrease is large enough, the carrier will be better off serving both shipper types by offering contracts $B$ and $C$ (which are not prevented by the liability limit). Thus, by effectively preventing the carrier from offering his preferred contract to just the high value shipper, a liability limit can induce the carrier to serve both shipper types, making both shipper types better off: the low value type is offered a zero rent contract, which requires that the high value shipper type be offered a positive rent contract.

For this reason, a mandatory liability ceiling can sometimes improve social welfare. The ceiling must be made mandatory, because a low value shipper who would otherwise be excluded from contracting under unlimited liability cannot simply bargain around this default and ask for a low price-low coverage contract. If the carrier offers such a contract, then he can no longer offer as profitable a contract to the high value shipper as is possible when low value shippers are excluded. Bargaining between low value shippers and the carrier thus involves an externality-the high value shipper's gain when the low value shipper is included-and is not generally efficient. 